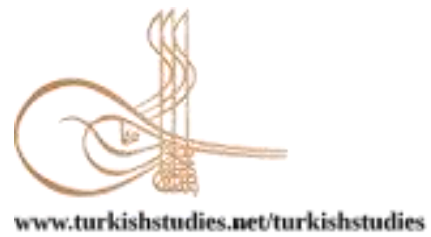

Turkish Studies

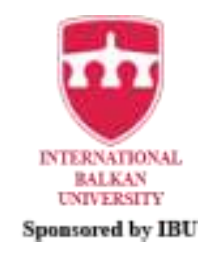

\title{
Türkiye’de Yabancı Dil Olarak Türkçe Öğretiminin Geldiği Son Nokta
}

Current Situation of Teaching Turkish as a Foreign Language

\author{
Bahar Doğan Kahtalı* - Büşra Günata ${ }^{* *}$
}

\begin{abstract}
This study aimed to examine the postgraduate theses written on teaching Turkish as a foreign language between 2014-2020 by classifying them according to the level of education, year, type of institute, subject area, research model, and universe/sample/study group. The document analysis method, one of the qualitative research methods, was used in the Study. The descriptive analysis method, one of the qualitative research methods that are used to describe and interpret the results, was used to analyze the data. Of the 263 theses written on teaching Turkish as a foreign language between 2014 and December 2020, 12, 21, 18, 22, 52,101 , and 37 were written in 2014, 2015, 2016, 2017, 2018, 2019, and 2020, respectively. The theses were examined in terms of the research model and it was found that the number of theses in which qualitative research models were used is greater. Regarding the distribution of the theses according to the variables of sample/study group/reviewed material etc., the number of book-document studies was the highest (128 theses). Regarding the subject areas of the theses, the most-studied topic were book-work review and usage (25 theses). Regarding the level of education of the 263 theses, 206 were master's theses and 57 were doctoral dissertations. Regarding the types of the institute of the theses, 145 prepared at the institute of Educational Sciences. The increase of such studies every day is important in terms of leading the field. This study can guide further research on teaching Turkish as a foreign language by offering integrity and provide convenience to researchers. This study can guide further research on teaching Turkish as a foreign language by offering integrity and provide convenience to researchers.
\end{abstract}

Structured Abstract: Introduction: In recent years, in which the need to know a foreign language has increased, teaching Turkish as a foreign language has become increasingly important. The interest in learning Turkish is increasing day by day, and in this context, various institutions are operating and Turkish language teaching centers and master's and doctoral programs are opened at universities. Turkish language teaching activities are carried out abroad through the Yunus Emre Institute and Turkish Maarif Foundation, established by the Republic of Turkey. Symposiums are held in Turkey related to this field and many books, articles, papers, and theses are written to guide the activities on teaching Turkish as a foreign language. The number of master's theses is increasing in recent years. Various studies examining the theses in this field were found in the reviews, but most of these studies do not cover the theses written in 2018, 2019, and 2020.

\footnotetext{
* Dr. Öğr. Üyesi, İnönü Üniversitesi, Eğitim Fakültesi, Türkçe ve Sosyal Bilimler Eğitimi Bölümü Asst. Prof. Dr., İnonu University, Faculty of Education, Turkish and Social Sciences Education ORCID 0000-0001-6184-2306

bahar.dogan@inonu.edu.tr

** Yüksek lisans öğrencisi, İnönü Üniversitesi, Eğitim Bilimleri Enstütüsü, Türkçe ve Sosyal Bilimler Ana Bilim Dalı Graduate student, İnonu University 
It was determined that about 200 theses were written on teaching Turkish as a foreign language in these three years. For this reason, the need for research involving current theses has emerged. The examination of these theses is important in that researchers who want to study in this field but cannot determine their thesis topics needed by the field can easily move forward according to the needs.

\section{Purpose}

This study aimed to examine the postgraduate theses written on teaching Turkish as a foreign language between 2014-2020 by classifying them according to the level of education, year, type of institute, subject area, research model, and universe/sample/study group.

\section{Method}

The document analysis method, one of the qualitative research methods, was used in the study. This method is preferred because it is considered the most appropriate method to investigate the trends of postgraduate academic studies conducted on teaching Turkish to foreigners in different fields in recent years. In this context, postgraduate theses that were written in Turkey between 2014-2020 on teaching Turkish as a foreign language were included in the study. 270 theses were reached as a result of the searches conducted among the theses in the database of The National Thesis Center of the Council of Higher Education of Turkey using the keywords of "teaching of Turkish as a foreign language," "teaching Turkish to foreigners," and "teaching Turkish as a foreign language." 7 of these theses with unauthorized access were not included in the study. The descriptive analysis method, one of the qualitative research methods that are used to describe and interpret the results, was used to analyze the data. The 263 theses were examined and interpreted according to the pre- determined themes, i.e. level of education, year, type of institute, subject area, research model, and universe/sample/study group.

\section{Findings, Discussion \& Conclusion}

Of the 263 theses written on teaching Turkish as a foreign language between 2014 and December 2020, 12, 21, 18, 22, 52, 101, and 37 were written in 2014, 2015, 2016, 2017, 2018, 2019, and 2020, respectively. Considering the distribution of the theses by year, it can be said that there occurred a partially continuous increase in the number of theses from 2014 to 2019. The highest number of the theses - 101 theses - was observed in 2019, while it significantly decreased to 37 in 2020. Türkben (2018) reported that 103 postgraduate theses were written between 2011-2015. However, it was observed in this study that 101 postgraduate theses were written only in 2019. Based on this fact, it can be said that there is a significant increase in the number of theses in this field. Büyükikiz (2014) reported that 93 postgraduate theses were written between 2006-2012. Ercan Güven (2015) reported that 25 theses were written in 2010 and Çelebi et al. (2019) reported that 20 theses were written between 2015-2017. These works do not cover the theses in 2018, 2019, and 2020. Current theses were also examined in this study. It can be said that there is a significant increase in the number of theses written in this field in the last three years.

The theses were examined in terms of the research model and it was found that the number of theses in which qualitative research models were used is greater. Regarding the 263 theses examined, qualitative, quantitative, and mixed research models were used in 123, 61, and 43 theses, respectively, and the research models of 38 theses were not identified. The finding that the qualitative research models are preferred more in the theses is parallel to the one found in Ercan Güven (2015), Büyükikiz (2014), Türkben (2018), and Çelebi et al. (2019).

Regarding the distribution of the theses according to the variables of sample/study group/reviewed material etc., the number of book-document studies was the highest (128 theses). This result is parallel to the one found in Ercan (2015) and Çelebi et al. (2019). Students were found to be the sample in 109 theses, while teachers were studied in 21 theses. The sample group was not identified in 5 theses.

Regarding the subject areas of the theses, the 5 most-studied topics were book-work review and usage (25), culture-transfer of culture (24), writing skill (21), grammar-linguistics (16), and speaking skill (14). It was found that mostly textbooks were studied in teaching Turkish as a foreign language. This result overlaps with the distribution of master's theses in terms of the topic in Çelebi et al. (2019). Remarkably, there are a small number of theses written on reading (10) and listening skills (8), which have an important place in language teaching. 
Regarding the level of education of the 263 theses, 206 were master's theses and 57 were doctoral dissertations. This result overlaps with the findings in Büyükikiz (2014), Ercan Güven (2015), Türkben (2018), and Çelebi et al. (2019).

Regarding the types of the institute of the theses, 145, 77, 37, and 4 theses were prepared at the institutes of Educational Sciences, Social Sciences, Turkic Studies, and Postgraduate Education, respectively. This result overlaps with the findings in Türkben (2018) and Çelebi et al. (2019). In these two studies, the theses were also written at institutes of Educational Sciences the most.

Some of the recommendations might be increasing the number of theses every year, showing a more balanced distribution in method and universe/sample/study group selection, focusing on the four basic language skills in topic selection, and increasing the number of doctoral dissertations. In this study, current results were revealed as all theses prepared around the identified key titles were held. For this reason, it can be said that this study is original. The increase of such studies every day is important in terms of leading the field. This study can guide further research on teaching Turkish as a foreign language by offering integrity and provide convenience to researchers. With this study, the current situation of teaching Turkish as a foreign language in Turkey was evaluated.

Keywords: Turkish education, Turkish teaching, Turkish as a foreign language, postgraduate theses.

Öz: Bu çalışmanın amacı; yabancı dil olarak Türkçe öğretimi alanında 2014-2020 yılları arasında hazırlanmış olan lisansüstü tezleri; eğitim düzeylerine, yapıldığı yıllara, enstitü türlerine, konu alanlarına, kullanılan araştırma modeline, evren/örneklem/çalışma gruplarına göre sınıflandırarak incelemektir. Çalışmada nitel araştırma yöntemlerinden doküman incelemesi yöntemi kullanılmıştır. Verilerin analizinde; bulguların betimlenerek yorumlanması amacıyla kullanılan nitel araştırma yöntemlerinden betimsel analiz kullanılmıştır. 2014-2020 yılının Aralık ayına kadar olan dönemde yabancı dil olarak Türkçe öğretimi ile ilgili hazırlanmış 263 tezin 12'sinin 2014 yılında, 21'inin 2015 yılında, 18'inin 2016 y1lında, 22'sinin 2017 yılında, 52'sinin 2018 yılında, 101 'inin 2019 yılında ve 37'sinin 2020 yılında hazırlandığ görülmektedir. Tezler, araştırma modeli bakımından incelendiğinde nitel araştırma modellerinin kullanıldığı çalışmaların sayısal açıdan fazla olduğu tespit edilmiştir. Tezlerin örneklem/çalışma grubu/incelenen materyal vb. değişkenlerine göre dağılımına bakıldığında en fazla 128 tez ile kitap-doküman çalışmaları olmuştur. Tezlerin konu alanlarına bakıldığında 25 tez ile en çok çalışılan konu kitap-eser inceleme ve kullanımıdır. Tezler türlerine göre incelendiğinde 263'ün tezin 206's1 yüksek lisans 57'si doktora tezidir. Tezlerin enstitü türlerine göre dağılımı incelediğinde 145'inin Eğitim Bilimleri Enstitüsünde hazırlandığı görülmektedir. Bu tür çalışmaların her geçen gün artması, alana yön vermesi bakımından önem taşımaktadır. Lisansüstü tezler, bu çalışma ve ilgili çalışmalar incelenerek alanın ihtiyaç duyduğu tez konuları belirlenebilir. Bu çalışma yabancı dil olarak Türkçe öğretimi alanında yapılacak yeni çalışmalar için bütünlük sunarak yol gösterici olabilir ve araştırmacılara kolaylık sağlayabilir.

Anahtar Kelimeler: Türkçe eğitimi, Türkçe öğretimi, yabancı dil olarak Türkçe öğretimi, lisansüstü tezler.

\section{Giriş}

Bireyler yaşadığı toplumda iletişim kurabilmek, insanları anlayabilmek ve kendini anlatabilmek için dili vasıta olarak kullanır. Dil bilmenin gerekliliğinin arttığı son yıllarda ülkeler arası ilişkilerin sağlanması için ana dili dışında yabancı dil bilmek ve etkili kullanmak gerekmektedir. Gelişmiş ve zengin bir dil olan Türkiye Türkçesi, yabancı dil olarak özellikle son yıllarda dünyada oldukça rağbet görmektedir ve bu durum de Türkçenin yabancı dil olarak öğretimi alanının ciddi olarak ele alınmasını gerekli kılmaktadır. Bu durumun yaşanma sebepleri arasında Başar (2021), Türkçenin yabancı/ikinci dil olarak öğretildiği coğrafyanın genişlemesini ve Türkiye'nin özellikle sınır komşularının yaşadıkları siyasi, sosyal ve ekonomik krizler nedeniyle Türkiye'ye göç etmelerini göstermektedir. "Türk imajının olumlu seyri, Türkçeyi yabancı dil olarak öğrenme süreçlerini olumlu etkilerken, oluşan talep sonrasında Türkiye ve Türk kültürüyle temas noktası olan Türkçe öğretim süreci de yine Türk imajını bundan sonraki süreçte 
etkileyeceğinden, bu noktada yapılanların, nihai olarak oluşturulmak istenen Türk imajına, Türkiye ile ilgili algıya hizmet edeceği de unutulmamalıdır" (Durmuş, 2013: 222).

Yabancı dil olarak Türkçe öğretiminin köklü bir temele dayandığı söylenebilir. Özbay (2021), bu tarihin Orhun Abidelerine kadar götürülebileceğini çünkü abidelerin bir yüzünün Çince olmasının o dönemde dillerin karşılıklı öğretildiğinin bir göstergesi olduğunu belirtmektedir. Ayrıca Özbay, Uygur döneminde de bu konuda çeşitli ipuçlarının varlığından söz etmektedir. Türklerin İslam'ı kabul etmesiyle birlikte yabancıların Türkçeyi öğrenme istekleride artmıştır. Bu istek neticesinde Türkçenin Arapçadan geride olmadığını kanıtlamaya çalışan ve ön sözünde Araplara Türkçe ögretmek amaciyla yazıldığı ifade edilen Divânu Lügati’t-Türk gibi bir şaheser Kaşgarlı Mahmud tarafından kaleme alınmıştır (Büyükikiz, 2014; Erdem, 2009).

Aslında geçmişten beri önem arz eden yabancı dil olarak Türkçe öğretimi, son 10 yıldır belki de hiç olmadığı kadar hızlı bir gelişim göstermektedir nitekim küreselleşmenin etkisiyle Türkçe öğrenimi talepleri artmış ve bu alana dair çalışmalar da bu durumdan etkilenmiştir. Türkiye'de bu çalışmaları sürdürmek amacıyla çeşitli adımlar atılmıştır ve üniversitelerde bu alanda ilerleme sağlayabilmek için çeşitli çalışmalar sürdürülmektedir. Eğitim Fakültelerinde Türkçe Öğretmenliği lisans programlarına yabancılara Türkçe öğretimi dersinin eklenmesi ve birçok üniversitenin enstitülerinde yabancı dil olarak Türkçe öğretimi yüksek lisans programlarının açılması yapılan çalışmalara örnek gösterilebilir. Yabancı dil olarak Türkçe öğretiminin kurumsallaşma sürecindeki asıl sıçrayışın 1984 yılında açılan Ankara TÖMER ile gerçekleştiği söylenebilir. Sonrasında 1992'de kurulan Türkiye İşbirliği Koordinasyon Ajansı Başkanlığ (TİKA), 2009 yılında kurulan Yunus Emre Enstitüsü ve 2016'da 6721 sayılı kanun ile kurulan Türkiye Maarif Vakfı ile kurumsallaşma süreci hızlanmıştır (Kardaş \& Kaya, 2019; Özdemir Erem, 2019; Uzun, 2018). Türkiye Cumhuriyeti tarafindan kurulan Yunus Emre Enstitüsü ve Türkiye Maarif Vakfı vasıtasıyla yurt dışında da Türkçe öğretim faaliyetleri yürütülmekte ve sürdürülmektedir. Türkiye'de bu alanla ilgili sempozyumlar düzenlenmekte ve yabanc1 dil olarak Türkçe öğretimi faaliyetlerine yön vermek amacıyla pek çok kitap, makale, bildiri ve tez hazırlanmaktadır. Lisansüstü eğitim düzeyinde hazırlanan tezlerin sayısı son yıllarda artış göstermektedir. Yapılan taramalarda bu alandaki tezleri inceleyen çeşitli çalışmalara rastlanmıştır ancak bu çalışmalar çoğunlukla 2018, 2019 ve 2020 yılındaki tezleri kapsamamaktadır. Bu üç yılda yabancı dil olarak Türkçe öğretimine dair 200'e yakın tez hazırlandığı belirlenmiştir. Bu nedenle güncel tezleri içeren bir araştırmanın gerekliliği ortaya çıkmıştır. Söz konusu tezlerin incelenmesi; bu alanda çalışma yapmak isteyen ancak alanın ihtiyaç duyduğu tez konularını belirleyemeyen araştırmacıların ihtiyaç doğrultusunda kolayca ilerleyebilmesini sağlaması açısından önem taşımaktadır. Yapılan taramalar sonucunda yabancı dil olarak Türkçe eğitimi konulu tezlerin incelendiği farklı makalelere rastlanmıştır. Bu çalışmalardan Büyükikiz (2014) ve Ercan Güven'in (2015) yaptığ1 çalışmalar 2012-2013 yıllarına kadar hazırlanmış olan tezleri ele almıştır. Bu iki çalışmanın içerik olarak detaylı olduğu görülse de günümüz için yıl kapsamı bakımından ihtiyacı karşılamadığı söylenebilir.

Büyükikiz (2014) araştırmasında, bu alanda 1981-2012 yılları arasında hazırlanan 147 lisansüstü tezi incelemiştir. Sözü edilen çalışmada tarama modeli kullanılmış ve verilerin toplanmasında tezler bilhassa "yabancılara Türkçe öğretimi" kavramı etrafında yoğunlaştırılmıştır. $\mathrm{Bu}$ tezlerin 125 'i yüksek lisans 22 ' si ise doktora tezidir. Çalışmada elde edilen verilere göre lisansüstü tezlerin çoğunluğunu yüksek lisans tezleri oluşturmuştur. Tezlerin yıllara göre dağılımına bakıldığında ise en çok tezin 2006-2012 yılları arasında hazırlandığ 1 belirlenmiştir. Araştırmacı tezlerin konu alanlarını on farklı başlıkta sunmuştur. Bu başlıklara göre en fazla tezin dil bilgisi alanında hazırlandığı belirtilmiştir. Çalışmanın sonuç ve öneriler kısmında bazı hususlara dikkat çekilmiştir. Bu hususların göze çarpanlarından biri yabancılara Türkçe Öğretimi alanındaki tezlerin son yıllarda yoğunlaştığı fakat yoğunlaşma yaşansa da bu sayıların yetersiz olduğudur. 
Ercan Güven (2015) makalesinde 1989- 2013 yıllarında tamamlanmış lisansüstü tezleri incelemiştir. $\mathrm{Bu}$ makale diğer üç çalışmayla kıyaslandığında en detaylı başlıkların sunulduğu çalışma olarak nitelendirilebilir. Çalışma ile 172 tez incelenmiş ve bu tezler on iki farklı başlıkta analiz edilerek sunulmuştur.

Türkben (2018) makalesinde 1985-2017 y1llarında hazırlanan 270 lisansüstü tezi dokuz başlık altında inceleyerek sunmuştur. Sözü edilen çalışma 2018, 2019 ve 2020 yıllarında tamamlanan tezleri kapsamamaktadır.

Çelebi, Ergül, Usta \& Mutlu (2019), çalışmalarında 55 lisansüstü tezi incelemişlerdir. Çalışmada, 2009-2019 yılları arasında bu alanda hazırlanan tezler çeşitli başlıklar altında sinıflandırılarak değerlendirilmiş̧tir. Sözü edilen çalışma on yıllık bir süreci kapsadığı halde 55 tezle sınırlı kalmıştır. Bu nedenle çalışmanın tez sayısı kapsamı bakımından yeterli olmadığı söylenebilir. Söz konusu araştırmalar genel olarak değerlendirildiğinde dört çalışmanın da 2018, 2019 ve 2020 yılında hazırlanan lisansüstü tezleri içermediği söylenebilir. Ancak bu üç yıllık süreçte bu alanda hazırlanan tezlerin sayısının oldukça arttı̆̆ görülmüştür. Yeni çalışmalar yapacak araştırmacılara ve tez konusu seçiminde zorlanan öğrencilere güncel verileri sunma amacı, bu çalışmanın hazırlanmasını gerekli kılmıştır.

$\mathrm{Bu}$ çalışmanın amacı, yabancı dil olarak Türkçe öğretimi alanında 2014-2020 yılları arasında hazırlanmış olan lisansüstü tezleri; türlerine, yapıldığı yıllara, enstitü türlerine, konu alanlarına, kullanılan yönteme, evren/örneklem/çalışma gruplarına göre sınıflandırarak incelemektir.

Bu çalışmada şu alt amaçlara ilişkin sorulara cevap aranmıştır:

1. Tezlerin türleri nedir?

2. Tezlerin yapıldıkları enstitülere göre dağılımı nasıldır?

3. Tezlerin yıllara göre dağılımı nasıldır?

4. Tezlerin konu alanlarına göre dağılımı nasıldır?

5. Tezlerin araştırma modeline göre dağılımı nasıldır?

6. Tezlerin evren/örneklem/çalışma gruplarına göre dağılımı nasıldır?

\section{Yöntem}

\section{Araştırmanın Modeli}

Çalışma doküman incelemesi yöntemi ile oluşturulmuştur. Payne \& Payne'e (2004: 60) göre doküman incelemesi, fiziksel kaynakların sınıflandırılması, araştırılması, yorumlanması ve sınırlarının belirlenmesi için kullanılan tekniklerdir. Bu yöntemin tercih edilme nedeni, yabancılara Türkçe eğitiminde son yıllarda yapılan lisansüstü akademik çalışmaların farklı alanlarda eğilimlerini araştırmak için en uygun yöntem olarak görülmesidir.

\section{İncelenen Tezler}

Araştırma kapsamında YÖK Ulusal Tez Merkezi veri tabanından elde edilen yabancı dil olarak Türkçe öğretimi alanındaki 263 lisansüstü tez incelenmiştir. Bu tezlerin 206 tanesinin yüksek lisans 57 tanesinin ise doktora tezi olduğu belirlenmiştir. Tezler; türlerine, yapıldığı yıllara, enstitü türlerine, konu alanlarına, kullanılan araştırma modeline, evren/örneklem/çalışma gruplarına göre sınıflandırılarak incelenmiştir.

\section{Verilerin Toplanması}


Veri toplama sürecinde tezler; "Türkçenin yabancı dil olarak öğretimi", "Türkçenin yabancılara öğretimi", "yabancılara Türkçe öğretimi", "yabancı dil olarak Türkçe öğretimi" anahtar kavramları ile toplanmıştır. Elde edilen 263 lisansüstü tez inceleme kapsamına dâhil edilmiştir.

\section{Verilerin Analizi}

Verilerin analizinde; bulguların betimlenerek yorumlanması amaciyla kullanılan nitel bir araştırma yöntemlerinden betimsel analiz kullanılmıştır. "Bu yaklaşıma göre, elde edilen veriler, daha önceden belirlenen temalara göre özetlenir ve yorumlanır' (Yıldırım \& Şimşek, 2016: 239). $\mathrm{Bu}$ çalışmada da önceden araştırmacılar tarafından belirlenen değişkenler (tezlerin türleri, yılları, yapıldıkları enstitüler, yöntem bilgileri) açısından ilgili çalışmalar incelenerek bulgular elde edilmiştir.

\section{Bulgular}

Çalışmanın bu bölümünde, belirlenen alt amaç cümleleri doğrultusunda incelenen 263 adet lisansüstü teze ait bulgular tablolar hâlinde sunulmuştur.

\section{İncelenen Tezlerin Türlerine Göre Dağılımı}

2014 yılından 2020 Aralık ayına kadar olan dönemde hazırlanan tezlerin türlerine göre dağılımı Tablo 5 'te verilmiştir.

Tablo 5: 2014-2020 Yılları Arasında Yabancı Dil Olarak Türkçe Öğretimi ile İlgili Tezlerin Türlerine Göre Dağılımı

\begin{tabular}{ll}
\hline Türler & $f$ \\
\hline Yüksek Lisans & 206 \\
Doktora & 57 \\
\hline Toplam & 263 \\
\hline
\end{tabular}

Tablo 5'e göre 2014 yılından 2020 Aralık ayına kadar olan dönemde hazırlanmış olan tezlerin türleri incelendiğinde 263 tezin 206'sının yüksek lisans, 57'sinin doktora tezi olduğu görülmektedir. Yüksek lisans tezlerinin doktora tezlerinden fazla olmasının nedeni yabancilara Türkçe eğitimi alanında yüksek lisans programlarının da gittikçe artmasından kaynaklanıyor olabilir.

\section{İncelenen Tezlerin Yapıldıkları Enstitülere Göre Dağılımı}

2014 yılından 2020 Aralık ayına kadar olan dönemde hazırlanan tezlerin enstitülere göre dağglımı Tablo 6'da verilmiştir.

Tablo 6: 2014-2020 Yılları Arasında Yabancı Dil Olarak Türkçe Öğretimi ile İlgili Tezlerin Hazırlandıkları Enstitülere Göre Dağılımı

\begin{tabular}{ll}
\hline Enstitü Türü & $f$ \\
\hline Eğitim Bilimleri & 145 \\
Sosyal Bilimler & 77 \\
Türkiyat Araştırmaları & 37 \\
Lisansüstü Eğitim & 4 \\
\hline Toplam & 263 \\
\hline
\end{tabular}


Tablo 6'ya göre göre 2014 yılından 2020 Aralık ayına kadar olan dönemde yabancı dil olarak Türkçe öğretimi ile ilgili hazırlanmış tezlerin enstitü türleri incelendiğinde 263 tezin 145'inin eğitim bilimleri, 77'sinin sosyal bilimler, 37'sinin Türkiyat Araştırmaları, 4'ünün lisansüstü eğitim enstitüsünde hazırlandığı görülmektedir. Türkiyat araştırmaları enstitüsünde hazırlanan tezlerin tamamı Hacettepe Üniversitesi bünyesinde hazırlanmıştır. Lisansüstü eğitim enstitüsünde hazırlanan tezler; Ankara Hacı Bayram Veli Üniversitesi, Bartın Üniversitesi, Uşak Üniversitesi, Tokat Gaziosmanpaşa Üniversitesi bünyesinde hazırlanmıştır.

\section{İncelenen Tezlerin Yıllara Göre Dağılımı}

2014 yılından 2020 Aralık ayına kadar olan dönemde hazırlanan tezlerin yıllara göre dağılımı Tablo 1'de verilmiştir.

Tablo 1: 2014-2020 Yılları Arasında Yabancı Dil Olarak Türkçe Öğretimi ile İlgili Tezlerin Y1llara Göre Dağılımı

\begin{tabular}{ll}
\hline Y1l & $f$ \\
\hline 2014 & 12 \\
2015 & 21 \\
2016 & 18 \\
2017 & 22 \\
2018 & 52 \\
2019 & 101 \\
2020 & 37 \\
\hline Toplam & 263 \\
\hline
\end{tabular}

Tablo 1'e göre göre 2014-2020 y1lının Aralık ayına kadar olan dönemde hazırlanan 263 tezin 12'sinin 2014 y1lında, 21'inin 2015 y1lında, 18'inin 2016 y1lında, 22'sinin 2017 y1lında, 52'sinin 2018 yılında, 101'inin 2019 yılında ve 37'sinin 2020 yılında hazırlandığ görülmektedir. Yabancılara Türkçe öğretimi alanında her geçen yıl çoğunlukla daha fazla tez çalıșmasına yer verildiği, bununla birlikte özellikle 2019 yılında alandaki çalışmaların büyük oranda arttı̆̆ tablo sonuçlarından çıkarılabilir. $\mathrm{Bu}$ da son yıllarda araştırmacılaırn daha çok bu alana yöneldiğini göstermektedir. 2020 yılında yaşanan düşüşün sebebi tüm dünya gibi Türkiye'yi de birçok açıdan olumsuz etkileyen salgın nedeniyle olabilir.

\section{İncelenen Tezlerin Konularına Göre Dağılımı}

2014 yılından 2020 Aralık ayına kadar olan dönemde hazırlanan tezlerin konularına göre dağılımı Tablo 4'te verilmiştir.

Tablo 4: 2014-2020 Yılları Arasında Yabancı Dil Olarak Türkçe Öğretimi ile İlgili Tezlerin Konularına Göre Dağ 11 ımı

\begin{tabular}{ll}
\hline \multicolumn{1}{c}{ Konu Dağılımı } & $f$ \\
\hline Kitap-eser & 25 \\
Kültür-kültür aktarımı & 24 \\
Diğer & 22 \\
Yazma & 21
\end{tabular}

www.turkishstudies.net/turkishstudies 
Dil bilgisi- dilbilim

Konuşma

Kelime Öğretimi

Atasözü-deyim

Okuma

Söz varlığg1

Düzenleme-uyarlama

Dinleme

Ölçme ve Değerlendirme

Öğretmen görüşleri

Öğrenci görüşleri

Karşılaştırma

Drama-tiyatro kullanımı

Sadeleştirme

Diller İçin Avrupa O.B.M.

Film-KısaFilm Kullanımı

Dil İhtiyaçları

Sözlük Geliștirme

Çocuklara Öğretim

Derlem

Teknoloji Kullanımı

Yenilenmiş Bloom T.

Materyal Geliştirme

Etkinlik Geliştirme

Sorunlar ve Çözüm Ö.

Aktif Öğrenme

Akademik Okuryazarlık

Bilgisayar Destekli Ö.

Çoklu Zekâ

Dijital Öykü Kullanımı

Dede Korkut H. Kullanımı

Eğitsel Oyun Kullanımı 
Türk Masalları

1

Yeterlikler
1

Toplam 263

Tablo 4'e göre 2014 yılından 2020 Aralık ayına kadar olan dönemde hazırlanmış olan tezlerin konularına göre dağılımı incelendiğinde 25 kitap-eser inceleme ve kullanımıyla ilgili, 24 kültür-kültür aktarımıyla ilgili, 21 yazmayla ilgili, 16 dil bilgisi-dilbilimle ilgili, 14 konuşmayla ilgili, 13 kelime öğretimiyle ilgili, 13 atasözü-deyimle ilgili, 12 okumayla ilgili, 12 söz varlığıyla ilgili, 11 düzenleme-uyarlama çalışmalarıla ilgili, 8 dinlemeyle ilgili, 7 ölçme ve değerlendirmeyle ilgili, 7 öğretmen görüşleriyle ilgili, 5 öğrenci görüşleriyle ilgili, 5 karşılaştırma çalışmalarıyla ilgili, 5 drama-tiyatro kullanımıyla ilgili, 5 sadeleştirmeyle ilgili, 4 Diller İçin Avrupa Ortak Başvuru Metniyle ilgili, 3 kısa film-film kullanımıyla ilgili, 3 dil ihtiyaçlarıyla ilgili, 3 sözlük geliştirmeyle ilgili, 3 çocuklara yabancı dil olarak Türkçe öğretimiyle ilgili, 2 derlem çalışmalarıyla ilgili, 2 teknoloji kullanımıyla ilgili, 2 yenilenmiş bloom taksonomisiyle ilgili, 2 materyal geliştirmeyle ilgili, 2 etkinlik geliştirmeyle ilgili, 2 sorunlar ve çözüm önerileriyle ilgili, 1 aktif öğrenme, akademik okuryazarlık, bilgisayar destekli öğretim, çoklu zekâ, dijital öykü kullanımı, Dede Korkut Hikâyelerinin kullanımı, eğitsel oyun kullanımı, şarkı kullanımı, Türk masalları, yeterliklerle ilgili tez hazırlandığı görülmektedir. Dolaylı-dolaysız anlatım, Türkçenin yabanc1 dil olarak öğretimine İngiliz katkısı, öğrenen özerkliği, Altayistik inceleme, dil öğrenme stratejileri, iş tatmini ve tükenmişlik düzeyleri, iki dillilik gibi genel başlık kapsamına dâhil edilemeyen konular "diğer" başlığında yer almıştır. Son beş yılda alanda konu dağılımına bakıldığında konuların daha çok kaynak kitapların incelenmesine yönelik olduğu görülmüştür. İkinci çok tercih edilen konu ise kültür aktarımıyla ilgilidir. Dört temel dil becerisine yönelik çalışmalarda ise konu dağılımı yazma, konuşma, okuma ve dinleme şeklindedir. Dinleme çalışmalarına ana dili eğitiminde olduğu gibi Türkçenin ikinci dil olarak öğretiminde de henüz çok fazla çalışılmayan konular arasındadır.

\section{İncelenen Tezlerin Kullanılan Araştırma Modeline Göre Dağılımı}

2014 yılından 2020 Aralık ayına kadar olan dönemde hazırlanan tezlerin kullanılan araştırma modeline göre dağılımı Tablo 2'de verilmiştir.

Tablo 2: 2014-2020 Yıılları Arasında Yabancı Dil Olarak Türkçe Öğretimi ile İlgili Tezlerin Araştırma Modeline Göre Dağılımı

\begin{tabular}{ll}
\hline Araştırma Modeli & $f$ \\
\hline Nitel & 123 \\
Nicel & 61 \\
Karma & 43 \\
Belirtilmemiş & 36 \\
\hline Toplam & 263 \\
\hline
\end{tabular}

Tablo 2'ye göre 2014 yılından 2020 Aralık ayına kadar olan dönemde hazırlanan tezlerin araştırma modeline göre dağılımı incelendiğginde en çok nitel çalışma yapıldığı görülmektedir. 263 çalışmanın 123'ü nitel, 61'i nicel, 43'ü karma yöntemle şekillenmiştir. Nicel çalışmalarda örneklem büyüklüğünün önemli olması ve bununla birlikte dil sınıflarında öğrenci sayısının az olması araştırmacıları nicel çalışmalardan ziyade nitel araştırmalara yöneltmiş olabilir. Türkiye'deki yabancı öğrenci sayısının yıllar içerisinde artmasıyla alanda daha çok deneysel ya da 
tarama modelinde tezler yapılabilir. Ayrıca Tablo 2'de dikkat çeken birkaç sonuç ise 36 çalışmada yöntem bilgisinin olmayışıdır. Bilimsel bir tezde herhangi bir yöntemin olmaması bilimsel açıdan çok mümkün olmayacaktır ancak raporlama kısmında araştırmacıların konu ya da dikkat eksikliği neticesinde böyle bir sonuç ortaya çıkmış olabilir.

\section{İncelenen Tezlerin Evren/Örneklem/ Çalışma Grubuna Göre Dağılımı}

2014 yılından 2020 Aralık ayına kadar olan dönemde hazırlanan tezlerin evren/örneklem/çalışma grubuna göre dağılımı Tablo 3’te verilmiştir.

Tablo 3: 2014-2020 Yılları Arasında Yabancı Dil Olarak Türkçe Öğretimi ile İlgili Tezlerin Evren/Örneklem/Çalışma Grubuna Göre Dağılımı

\begin{tabular}{ll}
\hline Evren/Örneklem/Çalışma Grubu & $f$ \\
\hline Kitap-Doküman & 128 \\
Öğrenci & 109 \\
Öğretmen & 21 \\
Belirtilmemiş & 5 \\
\hline Toplam & 263 \\
\hline
\end{tabular}

Tablo 3'e göre 2014 yılından 2020 Aralık ayına kadar olan dönemde yabancı dil olarak Türkçe öğretimi ile ilgili hazırlanmış tezlerin örneklemlerine göre dağılımı incelendiğinde kitapdoküman ile çalışılmış 128 tez, öğrencilerle çalışılmış 109 tez, öğretmenlerle çalışılmış 21 tez ve örneklem grubu belirtilmemiş olan 5 tez olduğu görülmektedir. Tezlerde daha çok alandaki kaynaklara yönelik çalışmalar yapıldığı görülmektedir. Dil öğretiminde kaynaklar tabii ki önemli bir araçtır ve incelenmelidir ancak kaynaklara ulaşılabilirliğin daha kolay olması böyle bir sonucu doğurmuş da olabilir. Kaynaklardan sonra alanda en çok çalışma öğrencilerle yapılmıştır. Öğrencilerle yapılan araştırmaların zamanla yaygınlaşmasının alana farklı bir bakış açısı getirebileceği düşünülmektedir. Nitekim dil öğretiminde yapılması planlanan tüm yenilikler öğrencilerin hedef dil becerilerini daha iyi konuma getirmek içindir.

\section{Tartışma, Sonuç ve Öneriler}

Türkçe öğrenenlerin artış göstermesi ve Türkçenin dünya dili olması hedeflenen bir durumdur. Bu nedenle yabancı dil olarak Türkçe öğretimini konu alan çalışmaların ele alınması ve bu alanla ilgili somut verilere ulaşılması önemlidir. 2014 yılından 2020 yılının Aralık ayına kadar olan dönemde yabancı dil olarak Türkçe öğretimi ile ilgili tezlerin araştırıldığı bu çalışmada 263 tez incelenmiştir. Tezler yıl, örneklem, araştırma modeli, konu, tür, enstitü başlıklarında bir araya getirilmiş ve tartışılmıştır. Bulgularda da belirtildiği üzere özellikle 2019 yılında alanla ilgili tezlerin sayısında ciddi bir artış söz konusudur. Bununla birlikte Memiş'in (2021: 42) "araştırma konularının birbirini tekrarlaması, konu alanlarının belirli bir çerçevede sıkışmış olması, araştırmalarda evreni yansıtabilecek örneklem büyüklüğüne ulaşılmaması, sorunların çözümü veya öğretim sürecinde kullanılabilecek içeriklerin üretiminden çok durum tespitine yönelik araştırmaların yapılması ve deneysel araştırmaların azlığ 1 vb." şeklinde belirttiği akademik olarak yabancı dil olarak Türkçe öğretiminin sorunları bu çalışmanın da genel sonuçları arasında yer almaktadır.

2014-2020 yılının Aralık ayına kadar olan dönemde yabancı dil olarak Türkçe öğretimi ile ilgili hazırlanmış tezlerin yıllara göre dağılımı incelendiğinde 263 tezin 12 'sinin 2014 yılında, 21'inin 2015 y1lında, 18'inin 2016 y1lında, 22'sinin 2017 y1lında, 52'sinin 2018 y1lında, 101'inin 2019 yılında ve 37'sinin 2020 yılında hazırlandığ 1 görülmektedir. Türkben (2018) yaptığ1 araştırmada 2011-2015 yıllarında 103 lisansüstü tez hazırlandığını belirtmiştir. Bu çalışmada ise 
sadece 2019 yılında 101 lisansüstü tez hazırlandığ görülmüştür dolayısıyla bu alandaki tezlerde ciddi bir artış yaşandığı söylenebilir. Büyükikiz (2014) çalışmasında 2006-2012 yıllarında 93 lisansüstü tez hazırlandığını belirtmiştir. Ercan Güven (2015) 2010 yılında 25 tez, Çelebi ve diğerleri (2019) 2015-2017 yıllarında 20 tez hazırlandığını belirtmiştir. Sözü edilen çalışmalar 2018, 2019 ve 2020 yılındaki tezleri kapsamamaktadır. Bu çalışma ile güncel tezler de incelenmiştir. İnceleme neticesinde son üç yılda bu alanda yapılan tez sayısında epeyce artış yaşandığı saptanmıştır. Bu duruma Türkiye'de Türkçe öğrenmek isteyen yabancı öğrencilerin sayısının her geçen yıl artması, Suriyeli sığınmacıların dil öğrenme istekleri ve yurt dışında da Türkçeye öğrenmeye dair ilginin artmasının da katkı sağladığı düşünülebilir. Sayının 2020 yılında düşüşü küresel boyutta yaşanan salgından kaynaklı olabilir. Çünkü yaşanan salgın birçok alanda olduğu gibi akademik çalışmaları da olumsuz etkiledi ve birçok öğrenci bu süreçte eğitimlerini dondurmak zorunda kaldılar.

2014 yılından 2020 Aralık ayına kadar olan dönemde yabancı dil olarak Türkçe öğretimi ile ilgili hazırlanmış tezlerin örneklem grubuna göre dağılımına bakıldığında en fazla çalışılan grup 128 çalışma ile kitap-doküman çalışmaları olmuştur. Bu sonuç, Ercan Güven (2015) ve Çelebi ve diğerlerinin (2019) yaptığı çalışmayla benzerlik göstermektedir. Büyükikiz'in (2014) ve Türkben'in (2018) yaptığı çalışmada örneklem grubuna göre dağılım belirtilmemiştir. Alanda kaynağa ulaşmak daha kolay olduğu için araştırmacılar tezlerinde daha çok kaynaklar üzerinde çalışmış olabilirler ancak dil öğretiminde öğrenciler, öğreticiler ile ilgili daha farklı çalışmaların yapılmadı alana daha çok katkı sağlayabilir.

Araştırmaya konu olan tezler araştırma modeli bakımından incelendiğinde nitel çalışmaların sayısal açıdan fazla olduğu tespit edilmiştir. İncelenen 263 makalenin 123'ü nitel, 61'i nicel, 43’ü karma yöntemler kullanılarak gerçekleştirilmiştir ve 36'sının yöntemi belirtilmemiştir. Makalelerde nitel yöntemin daha fazla tercih edilmesi ile ilgi bu bulgu, Ercan Güven'in (2015), Büyükikiz'in (2014), Türkben'in (2018) ve Çelebi ve diğerlerinin (2019) yaptığı çalışmayla paralellik göstermektedir. 2014 yılından 2020 Aralık ayına kadar olan dönemde yabancı dil olarak Türkçe öğretimi ile ilgili hazırlanmış tezlerin konularına göre dağılımı incelendiğinde konuların en fazla kitap-eser inceleme etrafinda şekillendiği görülmektedir. Bu sonuç, Çelebi ve diğerlerinin (2019) yaptığı çalışmada yüksek lisans tezlerinin konu dağılımları bakımından örtüşmektedir ancak doktora tezleri bağlamında örtüşmemektedir. Bu sonuç, Ercan Güven'in (2015), Türkben'in (2018) ve Büyükikiz'in (2014) yaptığı çalışmayla paralellik göstermemektedir çünkü sözü edilen çalışmalarda en fazla dil bilgisi üzerine tez hazırlandığı belirtilmiştir. Alanda yapılan tezlerin daha çok nitel araştırmalar olması dil öğretim sınıflarında öğrenci sayısının azlığından kaynaklanabilir. Nicel araştırmalarda örneklem büyüklüğü önemli olduğu için araştırmacılar yeterli örnekleme ulaşmada sorun yaşadıkları için nicel çalışmaları tercih etmiyor olabilirler. Ancak dil öğretiminde özellikle dil becerilerinin gelişiminde farklı model, yöntem ve tekniklerin etkisinin araştırıldığı deneysel çalışmaların alana ciddi katkılar sağladığı düşünülürse alanda çalışma isteyen araştırmacıların nicel çalışmalara yönlendirilmesi uygun olabilir.

2014 yılından 2020 Aralık ayına kadar olan dönemde yabancı dil olarak Türkçe öğretimi ile ilgili hazırlanmış tezler türlerine göre incelendiğinde 263'ün tezin 206's1 yüksek lisans 57'si doktora tezidir. Bu sonuç, Büyükikiz'in (2014), Ercan Güven'in (2015), Türkben'in (2018) ve Çelebi ve diğerlerinin (2019) çalışmalarıyla örtüşmektedir. Sözü edilen dört çalışmada da yüksek lisans tezlerinin sayısı doktora tezlerine oranla oldukça yüksektir. 2014 yılından 2020 Aralık ayına kadar olan dönemde yabancı dil olarak Türkçe öğretimi ile ilgili hazırlanmış tezler enstitü türlerine incelendiğinde 263 tezin 145 'inin eğitim bilimleri enstitüsünde, 77'sinin sosyal bilimler enstitüsünde, 37'sinin Türkiyat araştırmaları enstitüsünde, 4'ünün lisansüstü eğitim enstitüsünde hazırlandığı görülmektedir. Bu sonuç, Türkben'in (2018) ve Çelebi ve diğerlerinin (2019) çalışmasıyla örtüşmektedir. Sözü edilen iki çalışmada da tezler en fazla eğitim bilimleri enstitüsü bünyesinde hazırlanmıştır. Büyükikiz (2014) ve Ercan Güven (2015) çalışmasında enstitü türlerine 
yer vermemiştir. Yüksek lisans tezlerinin doktora tezlerinden fazla olmasının nedeni yabancılara Türkçe eğitimi alanında yüksek lisans programlarının da gittikçe artmasından kaynaklanıyor olabilir. Türkçe eğitimi alanında doktora yapan ve farklı bir alana yönelmek isteyen öğrencilere akademik danışmanları bu alanda çalışma yapmalarını önerebilir. Nitekim incelenen tezlerin konu dağılımına bakıldığında alanda çalışılmayan ya da az çalışılan birçok konunun olduğu görülmektedir. Günceli takip eden araştırmacılar bu araştırma sonuçlarından yola çıkarak alanda eksik gördükleri konularda çalışma yapabilirler.

2014 yılıyla 2020 yılının Aralık ayına kadar olan zaman diliminde ortaya konmuş yabancı dil olarak Türkçe öğretimi ile ilgili çalışmaların incelendiği bu araştırmada ortaya konan bulgu, sonuç ve tartışma bölümüne göre yabancı dil olarak Türkçe öğretimi alanına ilişkin şu önerilerde bulunulabilir:

Yabancı dil olarak Türkçe öğretimi alanının önemi gittikçe artmaktadır. Bu alandaki açalışmaların artması alana yön verilmesi bakımından mühimdir. Tezlerin yıllara göre dağılımı incelendiğinde 2019 yılında 101 tez hazırlandığ 1 ancak bu sayısının 2020 yılında 37'ye düştüğü görülmektedir. İlgili çalışmaların her geçen yıl artması alan için faydalı olabilir. Bu nedenle yabancı dil olarak Türkçe öğretimi alanının ihmâl edilmemesi önerilebilir.

2014 yılıyla 2020 yılının Aralık ayına kadar olan zaman diliminde ortaya konmuş yabancı dil olarak Türkçe öğretimi ile ilgili çalışmaların örneklem grubunu çoğunlukla ders kitapları oluşturmaktadır. Yeni çalışmaların örneklem seçiminde daha dengeli bir dağılım göstermesi daha faydalı olabilir. Tezlerin büyük bir bölümünü nitel çalışmalar oluşturmaktadır. Çoğunluğu nitel yöntemli tezlerin oluşturması literatür açısından daha dar kapsamlı sonuçlar ortaya koyabilir. $\mathrm{Bu}$ nedenle nicel ve karma yöntemli çalışmalar faydalı olabilir.

2014 yılından 2020 Aralık ayına kadar olan dönemde yabancı dil olarak Türkçe öğretimi ile ilgili hazırlanmış tezlerin konularına göre dağılımı incelendiğinde 25 kitap- eser inceleme çalışması yapıldığg görülmüştür. Ağırlığın dört temel dil becerisi ile ilgili çalışmalara yer verilmesi bu becerilerin geliştirilmesi için daha yararlı sonuçlar ortaya koyabilir. Çünkü uygun şartlar ve ortaam sağlandığı takdirde yabanc1 dil öğretiminde de tıpk1 ana dil öğretiminde olduğu gibi dinleme, konuşma, okuma ve yazma becerilerini öğretmek ve geliştirmek amaçlanır (Doğan, 2019).

263 lisansüstü tezin büyük bir çoğunluğunun yüksek lisans tezi olduğu görülmüştür. Doktora tezleri sayı bakımından yüksek lisans tezlerine kıyasla oldukça sınırlı kalmıştır. Bu durum; doktora eğitiminin yüksek lisans eğitimi kadar tercih edilmediği veya doktoraya devam eden araştırmacıların çalışmalarını bu alanda yapmadıkları şeklinde yorumlanabilir. Bu alandaki doktora çalışmalarının arttırılması önerilebilir.

$\mathrm{Bu}$ tür çalışmaların her geçen gün artması, alana yön vermesi bakımından önem taşımaktadır. Lisansüstü tezler, bu çalışma ve ilgili çalışmalar incelenerek alanın ihtiyaç duyduğu tez konuları belirlenebilir. Bu çalışma yabancı dil olarak Türkçe öğretimi alanında yapılacak yeni çalışmalar için bütünlük sunarak yol gösterici olabilir ve araştırmacılara kolaylık sağlayabilir.

\section{Kaynakça}

Başar, U. (2021). Yabancı dil olarak Türkçe öğretimi politikası nasıl olmalıdır? İçinde E. Boylu \& L. İltar (Ed.), Yabancı dil olarak türkçe ögretimi politika, program, yöntem ve öğretim (3. Bask1, ss. 29-61). Pegem Akademi Yayınc1lık.

Büyükikiz, K. (2014). Yabancılara Türkçe öğretimi alanında hazırlanan lisansüstü tezler üzerine bir inceleme. Mustafa Kemal Üniversitesi Sosyal Bilimler Enstitüsü Dergisi, 11(25), 203-213. 
Çelebi, C., Ergül, E., Usta, B. \& Mutlu, M. (2019). Türkiye'de yabanc1lara Türkçe öğretimi alanında hazırlanmış lisansüstü tezler üzerine bir meta-analiz çalışması. Temel Eğitim Dergisi, 1(3), 39-52.

Doğan, B. (2019). Yabancılara Türkçe öğretiminde dinleme/izleme eğitimi ve etkinlik örnekleri. İçinde İ. Erdem, B. Doğan \& H. Altunkaya (Eds.), Türkçenin yabancı dil olarak öğretimi (1. Basım, ss. 69-93). Pegem Akademi Yayıncılık.

Durmuş, M. (2013). Türkçenin yabanc1lara öğretimi: sorunlar, çözüm önerileri ve yabanc1lara Türkçe öğretiminin geleceğiyle ilgili görüşler, Adlyaman Üniversitesi Sosyal Bilimler Enstitüsü Dergisi Türkçenin Ĕ̈itimi Öğretimi Özel Sayısı, 11, 207-228.

Ercan Güven, A. N. (2014, 19-21 Haziran). Yabancılara Türkçe öğretimi üzerine yapılmış lisansüstü tezlerin çeşitli değişkenler açısından analizi. VII. Uluslararası Türkçenin Eğitimi-Öğretimi Kurultayı, Muğla, Türkiye.

Erdem, İ. (2009). Yabancılara Türkçe öğretimiyle ilgili bir kaynakça denemesi. Turkish Studies, $4 / 3,888-937$.

Kardaş, M. N. \& Kaya, M. (2019). Türkçenin yabancı dil olarak öğretiminin tarihçesi. İçinde M.N. Kardaş (Ed.), Türkçenin yabancı dil olarak ögretimi (1. Basım, ss. 1-25). Pegem Akademi Yayınc1lik.

Memiş, M. (2021). Yabancılara Türkçe öğretiminin güncel sorunları (1. Baskı). Pegem Akademi Yayınc1lik.

Özbay, M. (2021). Yabancı dil olarak Türkçe öğretiminin akademik programalrdaki yeri. İçinde E. Boylu (Ed.). Soru ve cevaplarla yabancı dil olarak Türkçe ögrretimi el kitabı. (1. Bask1, 9596). Pegem Akademi Yayıncilık.

Özdemir Erem, N. H. (2019). Türkçenin yabancı dil olarak öğretiminin tarihsel temelleri. İçinde İ. Erdem, B. Doğan \& H. Altunkaya (Eds.), Türkçenin yabancı dil olarak ögretimi (1. Basım, ss. 3-11). Pegem Akademi Yayıncıl1k.

Payne, G., \& Payne, J. (2004). Key concepts in social research. Sage Publications.

Türkben, T. (2018). Yabancı dil olarak Türkçe öğretimi alanında yapılan lisansüstü çalışmaların değerlendirilmesi. Uluslararası Türkçe Edebiyat Kültür Ĕgitim Dergisi, 7(4), 2464-2479.

Uzun, E. (2018). Yabancılara Türkçe öğretiminde yeni gelişmeler üzerine. İçinde A. Şahin (Ed.), Yabancı dil olarak Türkçe ögretimi/kuramlar, yaklaşımlar, etkinlikler (2. Basım, ss. 677681). Pegem Akademi Yayınc1lık.

Yıldırım, A. \& Şimşek, H. (2016). Sosyal bilimlerde nitel araştırma yöntemleri. Seçkin Yayıncılık.

\section{İncelenen Tezler}

Abuammar, R.J.A. (2018). Yabancllara Türkçe ögrretiminde program sorununun ögrretim sürecine yansıması. [Yayımlanmamış Yüksek Lisans Tezi]. Sakarya Üniversitesi.

Abukan, M. (2018). Türkçenin yabancı dil olarak öğretiminde yazmak için konuş modelinin üretici becerilere etkisi. [Yayımlanmamış Doktora Tezi]. Atatürk Üniversitesi.

Açıkgöz, E.S. (2018). Yabancı dil olarak Türkçe öğretimi ders kitaplarında kültür aktarımı: Yeni Hitit Yabancılar İçin Türkçe Ders Kitabı: (A1-A2 düzeyi). [Yayımlanmamış Yüksek Lisans Tezi]. Gaziosmanpaşa Üniversitesi.

Açıkgöz, N. (2019). Yabancı dil olarak Türkçe öğretiminde kültürlerarası duyarlılı̆̆ın gelişiminde dramanın rolü. [Yayımlanmamış Yüksek Lisans Tezi]. Dokuz Eylül Üniversitesi. 
Akcaoğlu, C. (2017). Somut olmayan kültürel miras ve yabancı dil olarak Türkçe öğretiminde kullanımı. [Yayımlanmamış Yüksek Lisans Tezi]. Hacettepe Üniversitesi.

Aksoy, H. (2015). Türkçenin yabancı dil olarak ögretimi alanında hazırlanan kitap setlerinde yer alan değerler üzerine bir inceleme. [Yayımlanmamış Yüksek Lisans Tezi]. Mevlana Üniversitesi.

Aktan, F. (2019). Yabancılara Türkçe ögrretiminde Halide Edip Adıvar'ın himmet çocuk hikâyesinin B1-B2 düzeyinde sadeleştirilmesi ve etkinlik hazırlanması. [Yayımlanmamış Yüksek Lisans Tezi]. Çanakkale Onsekiz Mart Üniversitesi.

Akyüz, S.G. (2019). Yabancı dil olarak Türkçe öğretiminde Dede Korkut Hikâyeleri'nden yararlanılması. [Yayımlanmamış Yüksek Lisans Tezi]. Hacettepe Üniversitesi.

Aldemir, Ü. (2020). Yabancllara Türkçe ögrretiminde kaynak eserler (Kitâbu'l-İdrâk li-Lisâni'lAtrâk örneği). [Yayımlanmamış Doktora Tezi]. Marmara Üniversitesi.

Altaç, E. (2020). Edebi bir metin türü olan tiyatronun yabancı dil olarak Türkçe ögrretiminde kullanımı ve dört beceriye katkısı. [Yayımlanmamış Yüksek Lisans Tezi]. Hacettepe Üniversitesi.

Altay, M. (2020). Türkçenin yabancı dil olarak ögretiminde öğrenme amaçl mektup yazma etkinliğinin kullanılması. [Yayımlanmamış Yüksek Lisans Tezi]. Akdeniz Üniversitesi.

Aramak, K. (2016). Türkçenin yabancı dil olarak öğretiminde bağdaşıklık araçlarının kullanım düzeyi üzerine bir araştırma. [Yayımlanmamış Yüksek Lisans Tezi]. Gazi Üniversitesi.

Arslan, H. (2017). Türkçenin yabancı dil olarak ögretiminde duygu durumu bildiren ifadelerin ögrenilme düzeyleri. [Yayımlanmamış Yüksek Lisans Tezi]. Gazi Üniversitesi.

Arslan, N. (2014). Yabancılara Türkçe ögretimi ders kitaplarında söz varliğı unsurlarının incelenmesi. [Yayımlanmamış Yüksek Lisans Tezi]. Karadeniz Teknik Üniversitesi.

Arslan, N. (2016). Yabancılara türkçe öğretimi ders kitaplarındaki kalıpsözlerin karşılaştırmalı incelenmesi. [Yayımlanmamış Yüksek Lisans Tezi]. Çukurova Üniversitesi.

Arslan, N. (2018). Yabancı dil olarak Türkçe öğretiminde göreve dayalı ögrenme yönteminin A1A2 düzeyi konuşma becerisine katkısı. [Yayımlanmamış Doktora Tezi]. Hacettepe Üniversitesi.

Aşç1, Y. (2019). Yabancı dil olarak Türkçe ögrretiminde öykü: B2 düzeyinde okuma ve yazma becerisi geliştirme. [Yayımlanmamış Doktora Tezi]. Hacettepe Üniversitesi.

Ateş, A. (2016). Yabancılara Türkçe öğretiminde Gass'ın ikinci dil edinimi modeli'nin söz varlı̆̆ını geliştirmeye etkisi. [Yayımlanmamış Doktora Tezi]. İnönü Üniversitesi.

Avc1, M. (2019). Türkçenin yabancı dil olarak ögretiminde iletişimsel yöntemin ögrencilerin konuşma tutum ve başarılarına etkisi. (Somali örneği). [Yayımlanmamış Yüksek Lisans Tezi]. Kütahya Dumlupınar Üniversitesi.

Avc1, S. (2019). Tunus'ta yabancı dil olarak Türkçe ögretimine iki dilliliğin etkisi. [Yayımlanmamış Yüksek Lisans Tezi]. Kırıkkale Üniversitesi.

Avcu, Y.Ş. (2020). Yabancllara Türkçe ögretiminde seviyelere göre kelimelerin derinlik ve genişlik boyutlarının incelenmesi: Yedi iklim örneği. [Yayımlanmamış Yüksek Lisans Tezi]. Yıldız Teknik Üniversitesi.

Ayan, Z. (2016). Yabancı dil olarak Türkçe öğretiminde orta düzey yazma etkinliklerinin iletişimsel yaklaşım bağlamında değerlendirilmesi. [Yayımlanmamış Yüksek Lisans Tezi]. İstanbul Üniversitesi. 
Ayar, C. (2020). Yabancı dil olarak Türkçe ögretiminde kullanılan uyarlanmış metinlerin uyarlanma durumları üzerine bir inceleme. [Yayımlanmamış Yüksek Lisans Tezi]. Akdeniz Üniversitesi.

Aydemir, N. (2019). Yabancı dil olarak Türkçe öğretiminde deyim ve atasözlerinin bağlamdan anlamaya dönük video destekli ögretimi: Bir eylem araştırması. [Yayımlanmamış Yüksek Lisans Tezi]. Çanakkale Onsekiz Mart Üniversitesi.

Aydın, E. (2019). Yabancılara Türkçe ögrretiminde dijital hikâye anlatımının yaratıcı yazma becerisine etkisi. [Yayımlanmamış Doktora Tezi]. İnönü Üniversitesi.

Aydın, M. (2015). Yabancı dil olarak Türkçe öğretiminde kullanılan ders ve okuma kitaplarındaki kelime sıklığı ve seviyelere göre sözcük hazinesi çalışması. [Yayımlanmamış Yüksek Lisans Tezi]. Gazi Üniversitesi.

Aydoğan, K. (2018). Yabancl dil olarak Türkçe ögretiminde set halinde kullanılan "İstanbul" ve "Yedi iklim" metot kitaplarında okuma metinleri üzerine bir karşılaştırma ve kitaplara ilişkin TÖMER ögretim elemanlarının görüşleri. [Yayımlanmamış Yüksek Lisans Tezi]. Ondokuz Mayıs Üniversitesi.

Aydoğdu, İ. (2019). Türkçenin yabancı dil olarak öğretiminde cümle piramidi tekniğinin yazma eğitiminde kullanımı. [Yayımlanmamış Yüksek Lisans Tezi]. Sakarya Üniversitesi.

Ayhan, E. (2019). Yabancı dil olarak Türkçe ögrretiminde okuma metinlerinin seviyelerinin tespiti: Okuma sırasında göz izleme bulguları. [Yayımlanmamış Doktora Tezi]. Hacettepe Üniversitesi.

Ayık, S. (2019). Erken yaşta yabancı dil olarak Türkçe ögretimi: Oyunların yazma becerisine etkisi. [Yayımlanmamış Doktora Tezi]. Hacettepe Üniversitesi.

Ayten, H. (2019). Tahir Nejat Gencan'ın "Türkçe ögrreniyorum" adlı kitabının yabancılara Türkçe ögretimi açısından incelenmesi. [Yayımlanmamış Yüksek Lisans Tezi]. Zonguldak Bülent Ecevit Üniversitesi.

Baklacı, Ö. (2018). Yabancı dil olarak Türkçe öğretiminde görev odakl yöntem ışı̆̆ı̀nda yazma becerisinin geliştirilmesi. [Yayımlanmamış Yüksek Lisans Tezi]. İstanbul Üniversitesi.

Balkan, H. (2019). Yabancı dil olarak Türkçe öğretiminde etkileşimli kelime duvarı ile kelime ögretimi. [Yayımlanmamış Yüksek Lisans Tezi]. Kütahya Dumlupınar Üniversitesi.

Başar, U. (2019). Iran'da yabancı dil olarak Türkçe öğretimi. Yayımlanmamış Doktora Tezi, Hacettepe Üniversitesi.

Başkaya, K. (2019). Çocuklara yabancı dil olarak Türkçe ögrretiminde çocuk yazını metinlerinin kullanımına yönelik uygulamalı bir yaklaşım. [Yayımlanmamış Yüksek Lisans Tezi]. İstanbul Üniversitesi.

Başutktu, S. (2018). Türkçenin yabancı dil olarak öğretiminde B1 düzeyinde kelime öğretimi. [Yayımlanmamış Yüksek Lisans Tezi]. Başkent Üniversitesi.

Bayat, B.K. (2018). Yabancı dil olarak Türkçe ögretiminde akran değerlendirmesinin öğrencilerin yazma kaygısına etkisi. [Yayımlanmamış Yüksek Lisans Tezi]. Nevşehir Hacı Bektaş Veli Üniversitesi.

Bayraktar, F.B. (2015). Yabancılara Türkçe ögretiminde faydalanılan kitapların kültürel unsurların aktarımı açısından değerlendirilmesi. [Yayımlanmamış Yüksek Lisans Tezi]. Gazi Üniversitesi. 
Bayraktar, S. (2019). Yabancı dil olarak Türkçe ögretiminde bir kültür aktarım aracı olarak kalıp sözler. [Yayımlanmamış Doktora Tezi]. Hacettepe Üniversitesi.

Berk, R.R. (2019). Yabancı dil olarak Türkçe öğretiminde elektronik dinletilerin dinlediğini anlama başarısı ve dinleme kaygısına etkisi. [Yayımlanmamış Doktora Tezi]. Gazi Üniversitesi.

Berk, S.A. (2018). Yabancı dil olarak Türkçe öğretiminde dolaylı ve dolaysız anlatımlar. [Yayımlanmamış Yüksek Lisans Tezi]. Bilecik Şeyh Edebali Üniversitesi.

Biçer, N. (2015). Yabancllara Türkçe öğretiminde ögrenen özerkliği süreçlerinin incelenmesi. [Yayımlanmamış Doktora Tezi]. Atatürk Üniversitesi.

Boylu, E. (2019). Yabancılara Türkçe ögretiminde ölçme değerlendirme uygulamaları ve standart oluşturma. Yayımlanmamış Doktora Tezi, Çanakkale Onsekiz Mart Üniversitesi.

Boz, B.Y. (2020). Yabancılara Türkçe ögretiminde ikinci dil motivasyonel benlik sistemi ve ikinci dilde iletişim kurma istekliliği arasındaki ilişki. [Yayımlanmamış Yüksek Lisans Tezi]. Hacettepe Üniversitesi.

Bozkurt, B. (2015). Türkçenin yabancı dil olarak öğretiminde orta seviye (B1 - B2 Düzeyi) hedef sözcük belirleme çalışması. [Yayımlanmamış Yüksek Lisans Tezi]. Marmara Üniversitesi.

Bölükbaşı, C. (2019). Yabancı dil olarak Türkçe öğretiminde fiillerin belirlenmesi (A1 düzeyi). [Yayımlanmamış Yüksek Lisans Tezi]. Gazi Üniversitesi.

Bülbül, F. (2015). Yabancı dil olarak Türkçe öğretiminde okuduğunu anlama becerisinin kavram haritası aracıllğı̆la gelişstirilmesi: Bir eylem araştırması. [Yayımlanmamış Doktora Tezi]. Çanakkale Onsekiz Mart Üniversitesi.

Ceylan, F. (2019). Yabancılara Türkçe öğretiminde uygulanan sinıf içi etkinliklerine yönelik ögretmen ve ögrenci görüşleri. [Yayımlanmamış Yüksek Lisans Tezi]. Hacettepe Üniversitesi.

Crahay, S.R. (2019). Yabancı dil olarak Türkçe ögretimi Al düzeyinde kullanılmak üzere Türkçe konuşurların kullandıkları sözcük ve ifadelerin derlenerek bildirişim konuları altında sınıflandirılması. [Yayımlanmamış Yüksek Lisans Tezi]. Başkent Üniversitesi.

Çakır, A. (2015). Yabancı dil olarak Türkçe öğretiminde video kullanımının dinleme becerisine etkisi. [Yayımlanmamış Yüksek Lisans Tezi]. Çanakkale Onsekiz Mart Üniversitesi.

Çelebi, S. (2017). Yabancı dil olarak Türkçe öğretiminde görsel geri bildirim etkinlikleriyle gerçekleştirilen bürün öğretiminin sesli okuma becerisine etkisi. [Yayımlanmamış Doktora Tezi]. Atatürk Üniversitesi.

Çelik, B. (2017). Yabancılara Türkçe öğretiminde öğretmenin dili kullanma becerisi içinde konuşma. [Yayımlanmamış Yüksek Lisans Tezi]. Çanakkale Onsekiz Mart Üniversitesi.

Çelik, H. (2018). Yabancı dil olarak Türkçe ögretiminde kültürel ihtiyaç analizi. Yayımlanmamış Doktora Tezi, Hacettepe Üniversitesi.

Çelik, Y. (2019). Yabancı dil olarak Türkçe öğretiminde Suriyeli ögrrencilerin yazmada yaşadıkları zorluklar. [Yayımlanmamış Yüksek Lisans Tezi]. Kocaeli Üniversitesi.

Çetinkaya, E. (2018). Yabancılara Türkçe ögretimi ders kitaplarında kültürel unsurlar: yedi iklim Türkçe örneği. [Yayımlanmamış Yüksek Lisans Tezi]. Gaziosmanpaşa Üniversitesi.

Çevik, A. (2020). Yabancılara Türkçe öğretiminde bağlaçların kullanımı ve karşılaşılan problemler. [Yayımlanmamış Yüksek Lisans Tezi]. Fırat Üniversitesi. 
Çevik, B. (2019). Yabancı dil olarak Türkçe öğretiminde kullanılan Cl düzeyi ders kitaplarında disiplinler arasıllı. [Yayımlanmamış Yüksek Lisans Tezi]. Mersin Üniversitesi.

Çınar, N. (2019). Yabancı dil olarak Türkçe öğretiminde dramatizasyon yöntemi ile fiil öğretimi. [Yayımlanmamış Yüksek Lisans Tezi]. Hatay Mustafa Kemal Üniversitesi.

Dağdeviren, İ. (2019). Yabancllara Türkçe ögrretiminde efsane türü metinlerden hareketle kültür aktarımının değerlendirilmesi. [Yayımlanmamış Yüksek Lisans Tezi]. Uludağ Üniversitesi.

Dalak, H.D.E. (2017). Yabancı dil olarak Türkçe öğretiminde iletişimsel yaklaşımın deyim ögretimindeki başarıya etkisi. [Yayımlanmamış Yüksek Lisans Tezi]. Hacettepe Üniversitesi.

Delen, M. (2016). Yabancılara Türkçe öğretiminde filmlerin kullanımı (Selvi Boylum Al Yazmalım filmi örneği). [Yayımlanmamış Yüksek Lisans Tezi]. Gaziosmanpaşa Üniversitesi.

Deliktaş, A. (2019). Yabancı dil olarak türkçe ögretiminde dil ihtiyaç analizi: istanbul örneği. [Yayımlanmamış Yüksek Lisans Tezi]. İstanbul Üniversitesi.

Demir, F. (2017). Yabancı dil olarak Türkçe ögretiminde yazma becerisi gelişstirmeye yönelik öykü kullanımı: B2 düzeyi. [Yayımlanmamış Yüksek Lisans Tezi]. Hacettepe Üniversitesi.

Demir, H. (2015). Türkçenin yabancı dil olarak ögretiminde materyal ve teknik kullanımına ilişkin bir durum çalışması. [Yayımlanmamış Yüksek Lisans Tezi]. Çanakkale Onsekiz Mart Üniversitesi.

Demir, İ.N. (2020). Türkçenin yabancı dil olarak öğretimi için seviyelendirilmiş kurmaca metinlerin metindilbilimsel açıdan incelenmesi. [Yayımlanmamış Yüksek Lisans Tezi]. Kirıkkale Üniversitesi.

Demir, S. (2016). Yabancılara Türkçe öğretimi ders kitaplarında \{-Mış\} biçimbiriminin işlevlerinin incelenmesi. [Yayımlanmamış Yüksek Lisans Tezi]. Dokuz Eylül Üniversitesi.

Demircan, B. (2016). Yabancı dil olarak Türkçe öğretiminde Türk kültürüne ait değerlerin aktarılması amacına yönelik yazma ve okuma becerilerine dayalı materyal tasarımı. [Yayımlanmamış Yüksek Lisans Tezi]. İstanbul Üniversitesi.

Demirci, E.Ö. (2019). Yabancı dil olarak Türkçe öğretiminde şarkı kullanımı seviye A1. [Yayımlanmamış Yüksek Lisans Tezi]. Hacettepe Üniversitesi.

Demirci, R. (2019). Alfabe farklılıklarının yabancılara Türkçe öğretimindeki etkisi. [Yayımlanmamış Yüksek Lisans Tezi]. Van Yüzüncü Yıl Üniversitesi.

Demirel, İ.F. (2019). Yabancı dil olarak Türkçe ögretiminde uyarlanmış metinlerin okuduğunu anlama başarısına etkisi. [Yayımlanmamış Yüksek Lisans Tezi]. İstanbul Üniversitesi.

Dindar, D.E. (2019). Yabancılara Türkçe öğretiminde sözcük ögretim yollarının yabancı dil olarak Türkçe öğretimindeki ders kitaplarına yansıması. [Yayımlanmamış Yüksek Lisans Tezi]. Hacettepe Üniversitesi.

Dindar, D.E. (2019). Yabancılara Türkçe öğretiminde sözcük ögretim yollarının yabancı dil olarak Türkçe ögretimindeki ders kitaplarına yansıması. [Yayımlanmamış Yüksek Lisans Tezi]. Hacettepe Üniversitesi.

Doğan, B. (2019). Yabancı dil olarak Türkçe öğretiminde MEB öğretmenlerinin yaşadıkları zorluklar (Esenyurt örneği). [Yayımlanmamış Yüksek Lisans Tezi]. Çanakkale Onsekiz Mart Üniversitesi. 
Doğan, G. (2016). Yedi İklim Türkçe öğretim seti B1, B2 ve C1 seviyesi ders kitaplarındaki metinlerin yabancılara Türkçe ögretiminde kültür aktarımı açısından incelenmesi. [Yayımlanmamış Yüksek Lisans Tezi]. Başkent Üniversitesi.

Dolaşık, G. (2018). Yabancılara Türkçe öğretiminde kullanılacak metinlerin oluşturulma süreçleri. [Yayımlanmamış Yüksek Lisans Tezi]. Gazi Üniversitesi.

Dolmacı, M. (2015). Akademik Türkçe kelime bilgisi üzerine bir derlem çalışması: Yabancı dil olarak Türkçe ögrretimine dair çıkarımlar. [Yayımlanmamış Doktora Tezi]. Gazi Üniversitesi.

Durmuşcan, A. (2019). Yabancılara Türkçe ögretiminde fiillerin pandomim tekniği ile öğretiminin etkililiği. [Yayımlanmamış Yüksek Lisans Tezi]. Gaziantep Üniversitesi.

Dursun, B. (2017). Yabancllara Türkçe ögrretiminde film kullanımının öğrencilerin anlama becerisine etkisi. [Yayımlanmamış Yüksek Lisans Tezi]. Gaziosmanpaşa Üniversitesi.

Duru, H. (2014). Yabancı dil olarak Türkçe ögrretiminde kullanılan soruların nitelik araştırması. [Yayımlanmamış Doktora Tezi]. Çanakkale Onsekiz Mart Üniversitesi.

Dündar, Ş.N. (2019). Yabancllara Türkçe öğretiminde dinleme becerisinin bir web uygulaması aracıllğılyla geliştirilmesi. [Yayımlanmamış Yüksek Lisans Tezi]. Gazi Üniversitesi.

Ekmekçi, V. (2017). Yabancılara Türkçe öğretiminde akademik okuryazarlık öğretimine yönelik bir eylem araştırması. [Yayımlanmamış Doktora Tezi]. Erciyes Üniversitesi.

Elsıkma, H.İ. (2019). Türkçenin yabancı dil olarak öğretiminde kullanılan kısa filmlerin kültürel unsurlar açısından incelenmesi. [Yayımlanmamış Yüksek Lisans Tezi]. Kırıkkale Üniversitesi.

Emre, K. (2020). Türkçenin yabancı dil olarak öğretimi programının yenilenmiş bloom taksonomisine göre değerlendirilmesi. [Yayımlanmamış Yüksek Lisans Tezi]. Çanakkale Onsekiz Mart Üniversitesi.

Er, O. (2015). Yabancılara Türkçe öğretimi uygulamalarının kültürel farkındalık oluşturma açısından incelenmesi. [Yayımlanmamış Doktora Tezi]. Atatürk Üniversitesi.

Erdem, M.V. (2019). Yabancılara Türkçe öğretiminde çizgi film kullanımına ilişkin öğretici görüşlerinin incelenmesi. [Yayımlanmamış Yüksek Lisans Tezi]. Adıyaman Üniversitesi.

Erdoğan, G. (2019). Yabancılara Türkçe öğretimine yönelik ders kitaplarının atasözleri ve deyimler açısından incelenmesi. [Yayımlanmamış Yüksek Lisans Tezi]. Gaziantep Üniversitesi.

Eroğlu, S. (2015). Metindilbilimsel ölçütler çerçevesinde Ömer Seyfettin'in "Üç Nasihat" hikâyesinin yabancılara Türkçe ögretimi için sadeleştirme denemesi. [Yayımlanmamış Yüksek Lisans Tezi]. Gazi Üniversitesi.

Erol, H.F. (2014). Yabancl dil olarak Türkçe öğretiminde temel seviyede kelime edinimi. [Yayımlanmamış Doktora Tezi]. İstanbul Üniversitesi.

Erol, S. (2019). Yabancl dil olarak Türkçe öğretiminde eğitsel oyunların kullanımı. Yayımlanmamış Doktora Tezi, İnönü Üniversitesi.

Ersoy, İ. (2019). Yabancı dil olarak Türkçe öğretiminde kullanılan ders kitaplarındaki görsel ögelerin değerlendirilmesi. [Yayımlanmamış Yüksek Lisans Tezi]. Çanakkale Onsekiz Mart Üniversitesi. 
Fişekçioğlu, A. (2019). Yabancı dil olarak Türkçe öğretiminde diller için Avrupa ortak öneriler çerçevesi ölçütlerine göre Türk kültürü tanımlayıcılarının oluşturulması: B1 dil düzeyi model önerisi. [Yayımlanmamış Doktora Tezi]. Çanakkale Onsekiz Mart Üniversitesi.

Ganbarli, A. (2017). Yabancılara Türkçe ögrretiminde bağlaçlar. [Yayımlanmamış Yüksek Lisans Tezi]. Uludağ Üniversitesi.

Gedik, E. (2017). Yabancl dil olarak Türkçe öğretiminde ölçme ve değerlendirme. [Yayımlanmamış Yüksek Lisans Tezi]. İstanbul Arel Üniversitesi.

Golynska1a, A. (2017). Yabancı dil olarak Türkçe ögrretiminde tek dilli ögrrenici sözlüğ̈̈: Model, yöntem ve ilkeler. [Yayımlanmamış Yüksek Lisans Tezi]. İstanbul Üniversitesi.

Göçmen, Ç. (2019). Yabancı dil olarak Türkçe öğretiminde çeviri kullanımı üzerine öğrenici görüşleri. [Yayımlanmamış Yüksek Lisans Tezi]. İstanbul Üniversitesi.

Göçmen, E. (2018). Yabancı dil olarak Türkçe ögretiminde otantik dokümanların kullanımı ve AlA2 düzeyinde dil becerilerine etkisi. [Yayımlanmamış Doktora Tezi]. Hacettepe Üniversitesi.

Gök, V. (2020). Yabancılara Türkçe öğretimi için oluşturulmuş eğitsel web sitelerinin kullanılabilirlik ve öğretici görüşleri açısından değerlendirilmesi. [Yayımlanmamış Yüksek Lisans Tezi]. Düzce Üniversitesi.

Göktentürk, T. (2016). Yabancılara Türkçe öğretiminde ders materyalleri çok dilli bir sözlük örneği. [Yayımlanmamış Yüksek Lisans Tezi]. Marmara Üniversitesi.

Gül, A. (2019). Halk eğitimi merkezlerinde yabancı dil olarak Türkçe öğretiminde karşılaşılan problemlere dair öğretmen görüşleri: Ankara örneği. [Yayımlanmamış Yüksek Lisans Tezi]. Çanakkale Onsekiz Mart Üniversitesi.

Gülen, G. (2018). Yabancı dil olarak Türkçe ögrretiminde diksiyon. [Yayımlanmamış Yüksek Lisans Tezi]. İstanbul Üniversitesi.

Güler, S. (2019). Yabancı dil olarak türkçe öğretiminde/öğreniminde kelime kazanımına ilişkin oyun içerikli materyal geliştirme örneği: Bl düzeyi. [Yayımlanmamış Yüksek Lisans Tezi]. Hacettepe Üniversitesi.

Gülle, Z. (2019). Yabancılara Türkçe öğretiminde kültür aktarımının başka bir boyutu: Ders kitaplarının cinsiyet tercihi açısından incelenmesi. [Yayımlanmamış Yüksek Lisans Tezi]. Zonguldak Bülent Ecevit Üniversitesi.

Günaydın, Y. (2020). Türkçenin yabancı dil olarak öğretiminde etkileşimli okumanın konuşma becerisine etkisi. [Yayımlanmamış Doktora Tezi]. Yıldız Teknik Üniversitesi.

Gündoğdu, İ. (2019). Kültürler arası iletişim yaklaşımı açısından Türkçenin yabancı dil olarak ögretiminde kullanılan ders kitaplarındaki deyimler. [Yayımlanmamış Yüksek Lisans Tezi]. Ondokuz Mayıs Üniversitesi.

Güneş, K. (2019). Yabancılara Türkçe öğretimi ders kitapları ile yabancı dil olarak İngilizce öğretimi ders kitaplarının tema ve tema içeriğindeki sözcükler açısından karşılaştırılması. [Yayımlanmamış Yüksek Lisans Tezi]. Sakarya Üniversitesi.

Güney, E.Z. (2019). Yabancılara türkçe öğretimi ders kitaplarında bulunan metin altı soruların yenilenmiş bloom taksonomisine göre analizi. [Yayımlanmamış Yüksek Lisans Tezi]. Çanakkale Onsekiz Mart Üniversitesi.

Güngör, A. (2020). Yabancı dil olarak Türkçe öğretiminde yazma becerisini geliştirmeye yönelik bir izlence önerisi. [Yayımlanmamış Doktora Tezi]. Hacettepe Üniversitesi. 
Güngör, H. (2019). Türkçenin yabancı dil olarak öğretiminde akıcı okuma: Durum çalışması. [Yayımlanmamış Doktora Tezi]. Bolu Abant İzzet Baysal Üniversitesi.

Gürbüz, N.E. (2018). Yabancılara Türkçe öğretiminde çoklu ortam materyali olarak geliştirilen zenginleş̧tirilmiş kitabın ögrenme üzerinde etkileri. [Yayımlanmamış Yüksek Lisans Tezi]. Atatürk Üniversitesi.

Gürel, A. (2020). Yabancı dil olarak Türkçe ögretiminde deyimlerin metinleştirilerek öğretimi: C1 seviyesi. [Yayımlanmamış Yüksek Lisans Tezi]. Uşak Üniversitesi.

Gürel, N. (2017). Türkçenin yabancı dil olarak öğretiminde bir materyal çalışması: Temalara uygun şarkılar oluşturma. [Yayımlanmamış Yüksek Lisans Tezi]. Kırıkkale Üniversitesi.

Gürler, H. (2017). Yabancılara Türkçe ögretiminde Sait Faik Abasıyanık'ın hikâyelerinin A1-A2 seviyesine uyarlanması. [Yayımlanmamış Yüksek Lisans Tezi]. Necmettin Erbakan Üniversitesi.

Gürler, S. (2017). Ömer Seyfettin'in hikâyelerinin yabancllara Türkçe ögrretiminde A1-A2 seviyesine uyarlanması. [Yayımlanmamış Yüksek Lisans Tezi]. Necmettin Erbakan Üniversitesi.

Gürsoy, E. (2019). Yabancı dil olarak Türkçe ögretiminde görev alan öğretmenlerin iş tatmini ve tükenmişlik düzeyleri. [Yayımlanmamış Yüksek Lisans Tezi]. Çanakkale Onsekiz Mart Üniversitesi.

Güvendik, T. (2019). Yabancı dil olarak Türkçe öğretiminde dil-kültür ilişsisi bağlamında yazınsal metinlerin temel söz varlığı açısından incelenmesi. [Yayımlanmamış Yüksek Lisans Tezi]. Nevşehir Hacı Bektaş Veli Üniversitesi.

Hafız, H.D. (2015). 8-12 yaş aralı̆̆ındaki çocuklara yabancı dil olarak Türkçe öğretimi. [Yayımlanmamış Yüksek Lisans Tezi]. Marmara Üniversitesi.

Hakım, M. (2019). Yabancı dil olarak Türkçe ögretiminde Türkçe-Urduca karşılaştırmalı zaman yapıları. [Yayımlanmamış Yüksek Lisans Tezi]. Dokuz Eylül Üniversitesi.

Hamaratlı, E. (2015). Yabancılara Türkçe öğretiminde kelime ă̆ oluşturma yönteminin ögrencilerin yazma becerisi ve motivasyonuna etkisi: Mısır örneği. [Yayımlanmamış Yüksek Lisans Tezi]. Bülent Ecevit Üniversitesi.

Hayran, T. (2019). Yabancılara Türkçe ögrretiminde kullanılan ders kitaplarında söz varlı̆̆ına yönelik bir inceleme. [Yayımlanmamış Yüksek Lisans Tezi]. Burdur Mehmet Akif Ersoy Üniversitesi.

Ioannıd1, C. (2020). Yabancı dil olarak Türkçe öğretiminde Türkçe-Yunanca insan vücudu ile ilgili deyim ve atasözlerinde dilsel ve kültürel benzerlikler. [Yayımlanmamış Yüksek Lisans Tezi]. Dokuz Eylül Üniversitesi.

Islıoğlu, S. (2015). Türkçe'nin yabancı dil olarak öğretiminde yaşanan sorunlar ve çözüm önerileri. [Yayımlanmamış Doktora Tezi]. Dokuz Eylül Üniversitesi.

Işıkoğlu, M. (2015). Yabancı dil olarak Türkçe öğretiminde kullanılan yeterlik sınavlarının madde yazımı bakımından incelenmesi: Mersin ve Sakarya Üniversiteleri örneği. [Yayımlanmamış Yüksek Lisans Tezi]. Atatürk Üniversitesi.

İhtiyarer, B. (2018). Türkçenin yabancı dil olarak öğretiminde görev odakl yaklaşım açısından kelime ögretimi. [Yayımlanmamış Yüksek Lisans Tezi]. İstanbul Üniversitesi. 
İltar, L. (2014). Yabancılara Türkçe ögretiminde Arapça-Türkçe ortak kelimeler yardımıyla etkinlik geliştirme ve uygulama: Mısır örneği. [Yayımlanmamış Yüksek Lisans Tezi]. Gazi Üniversitesi.

İltar, L. (2018). Türkçenin yabancı dil olarak ögretiminde kullanılan ders kitaplarındaki okuma metinlerinin farklı değişkenler açısından değerlendirilmesi. [Yayımlanmamış Doktora Tezi]. Gazi Üniversitesi.

İpek, M.E. (2018). Yabancılara Türkçe ögrretiminde metindilbilimsel ölçütler çerçevesinde Mustafa Kutlu'nun Ya Tahammül Ya Sefer isimli hikâyesinin sadeleştirilmesi. [Yayımlanmamış Yüksek Lisans Tezi]. Gazi Üniversitesi.

İskender, M. E. (2019). Yabancılara Türkçe ögrretiminde çoklu ortam materyalleri ile desteklenmiş halk anlatılarının kültür öğrenimi ve dil becerileri gelişimi üzerindeki etkisi. [Yayımlanmamış Yüksek Lisans Tezi]. Atatürk Üniversitesi.

J1lta, G. (2016). Yabancı dil olarak Türkçe ögretiminde ögrenene yönelik dil ihtiyaç analizi: Kosova örneği. [Yayımlanmamış Yüksek Lisans Tezi]. İstanbul Üniversitesi.

Kamalak, A. (2017). Yabancı dil olarak Türkçe öğretiminde yazdırmanın yazma yanlışlarının düzeltilmesine etkisi. [Yayımlanmamış Yüksek Lisans Tezi]. Çanakkale Onsekiz Mart Üniversitesi.

Kanca, E. (2020). Yabancılara Türkçe öğretimi ders kitaplarında görsel-metin иyumu. [Yayımlanmamış Yüksek Lisans Tezi]. Gaziosmanpaşa Üniversitesi.

Kaplan, N. (2017). Türkçenin yabancı dil olarak ögretiminde kullanılan ders kitaplarında karikatürlerin yeri. [Yayımlanmamış Yüksek Lisans Tezi]. Ankara Üniversitesi.

Kaplan, T. (2018). Yabancılara Türkçe öğretiminde otantik yazma çalışmalarının öğrencilerin yazma becerisi ve tutumuna etkisi. [Yayımlanmamış Doktora Tezi]. Sakarya Üniversitesi.

Kaptı, M. (2018). Yabancı dil olarak Türkçe öğretiminde geri bildirimle ilgili öğrenci görüşlerinin değerlendirilmesi. [Yayımlanmamış Yüksek Lisans Tezi]. Çanakkale Onsekiz Mart Üniversitesi.

Karadă̆, B.M. (2018). Yabancı dil olarak Türkçe öğretiminde eşdizimlilik. [Yayımlanmamış Yüksek Lisans Tezi]. İstanbul Üniversitesi.

Karakuş, O. (2018). Yabancılara Türkçe öğretimi ders kitaplarındaki metinlerde değer aktarımı referanslarının yeri. [Yayımlanmamış Yüksek Lisans Tezi]. Hatay Mustafa Kemal Üniversitesi.

Karalök, F. S. (2020). Yabancı dil olarak Türkçe öğretiminde dijital öykü kullanımının okuma motivasyonuna etkisi. [Yayımlanmamış Yüksek Lisans Tezi]. Nevşehir Hacı Bektaş Veli Üniversitesi.

Kaya, İ. (2019). Yabancı dil olarak Türkçe ögretiminde iletişimsel yaklaşımın A1-A2 seviyesinde konuşma becerisinde kullanılması. [Yayımlanmamış Doktora Tezi]. Erciyes Üniversitesi.

Kaya, N.N. (2019). Türk destanlarının yabancılara Türkçe öğretiminde kullanılacak metne uyarlanması. [Yayımlanmamış Yüksek Lisans Tezi]. Selçuk Üniversitesi.

Kaya, S. (2018). Türkçenin yabancı dil olarak ögretimi ders kitaplarında dil bilgisi. [Yayımlanmamış Yüksek Lisans Tezi]. Bolu Abant İzzet Baysal Üniversitesi.

Kayacan, S.G. (2018). Yabancı dil olarak Türkçe öğretiminde kalıp sözlerin kazandırılmasında yaratıcı dramanın etkisi. [Yayımlanmamış Doktora Tezi]. Atatürk Üniversitesi. 
Kayasandık, E. (2018). Yabancılara Türkçe öğretiminde kullanılan ders kitaplarındaki dil bilgisi ögretim yöntemlerinin incelenmesi. [Yayımlanmamış Yüksek Lisans Tezi]. Akdeniz Üniversitesi.

Kayatürk, N. (2018). Yabancılara Türkçe ögretimi kitaplarındaki metinlerin örtülü anlam unsurları açısından değerlendirilmesi (İstanbul yabancılara Türkçe öğretimi seti). [Yayımlanmamış Yüksek Lisans Tezi]. Hatay Mustafa Kemal Üniversitesi.

Kaymaz, Z. (2018). Yabancılara Türkçe ögretiminde Sabahattin Ali'nin apartman ve Köpek isimli hikâyelerinin al-a2 seviyesine uygun sadeleștirme çalışmast. [Yayımlanmamış Yüksek Lisans Tezi]. Ankara Yıldırım Beyazıt Üniversitesi.

Keser, S. (2018). Yabancı dil olarak Türkçe öğretiminde konuşma becerisinin gelişstirilmesinde karşılaşılan güçlükler. [Yayımlanmamış Yüksek Lisans Tezi]. Hacettepe Üniversitesi.

Keskin, H. (2019). Yabancı dil olarak Türkçe ögretiminde kullanılan "Yedi iklim Türkçe Öğretim Seti"nin çoklu zekâ kuramı açısından incelenmesi. [Yayımlanmamış Yüksek Lisans Tezi]. Bülent Ecevit Üniversitesi.

Keskin, M. (2018). Yabancı dil olarak Türkçe ögretimiyle ilgili haberlere yönelik söylem çözümlemesi: Bir uygulama. [Yayımlanmamış Yüksek Lisans Tezi]. Osmaniye Korkut Ata Üniversitesi.

K1lıç, F. (2019). Kültürel ögeler açısından yabancı dil olarak Türkçe ögretiminde kaynak incelemesi: Türkçeye Yolculuk B1-B2 ve Altay Türkçe Öğreniyorum B1-B2 örnekleri. [Yayımlanmamış Yüksek Lisans Tezi]. Sakarya Üniversitesi Eğitim Bilimleri Enstitüsü, Sakarya.

Kılınç, A.K. (2019). Yabancı dil olarak Türkçe öğretiminde/öğreniminde istek (rica) söz edimi. [Yayımlanmamış Yüksek Lisans Tezi]. Hacettepe Üniversitesi.

Kızdırıcı, F. (2017). Yabancı dil olarak Türkçe ögretiminde Avrupa Ortak Başvuru Metnine dayalı etkinlik tasarımı. [Yayımlanmamış Yüksek Lisans Tezi]. Gaziantep Üniversitesi.

Kiraz, E. (2018). Türkçenin yabancı dil olarak öğretiminde kullanılan metinlerde sözdizimsel yalınlaştırmanin okuma hızı ve kavrama düzeyine etkisinin incelenmesi. [Yayımlanmamış Yüksek Lisans Tezi]. Burdur Mehmet Akif Ersoy Üniversitesi.

Koçak, A. (2020). Yabancı dil olarak Türkçe ögretiminde telaffuz: Bir karma yöntem araştırması ve ünlülerin telaffuz ögretimine yönelik yeni bir teknik. [Yayımlanmamış Doktora Tezi]. Necmettin Erbakan Üniversitesi.

Koçak, N. (2019). Yabancılara türkçe öğretimi kitap setlerinde dil bilgisi öğretimi. [Yayımlanmamış Yüksek Lisans Tezi]. Kırıkkale Üniversitesi.

Koçak, S. (2018). Yabancı dil olarak Türkçe ögrretiminde temel düzeyde (A1-A2) konuşma izlence örneğinin hazırlanması. [Yayımlanmamış Yüksek Lisans Tezi]. Hacettepe Üniversitesi.

Koçer, T. (2014). Türkçe ögrretmenliği 3. ve 4. sinıf ögrencilerinin yabancılara Türkçe öğretimine yönelik öz-yeterlilik inançlarının araştırılması. [Yayımlanmamış Yüksek Lisans Tezi]. Çanakkale Onsekiz Mart Üniversitesi.

Kolçak, Ş. (2015). Yabancılara Türkçe ögretimi kapsamında Moğol ögrencilerin Türkçe ögrenme durumunun altayistik yönden incelenmesi. [Yayımlanmamış Yüksek Lisans Tezi]. Marmara Üniversitesi.

Koparan, B. (2019). Yabancı dil olarak Türkçe ögrretiminde Türk kültür ögelerinin aktarımına ilişkin ögrenci ve ögretim elemanı görüşleri ile ders kitaplarının incelenmesi. [Yayımlanmamış Yüksek Lisans Tezi]. Akdeniz Üniversitesi. 
Korkmaz, C.B. (2018). Yabancllara Türkçe öğretiminde dinleme metinlerin incelenmesi ve değerlendirilmesi. [Yayımlanmamış Doktora Tezi]. Gazi Üniversitesi.

Köylü, S.G. (2020). Yabancı dil olarak Türkçe ögrretiminde teknoloji kullanımının kaygı üzerine etkisi. [Yayımlanmamış Yüksek Lisans Tezi]. Bartın Üniversitesi.

Kurnaz, Ö. (2019). Yabancı dil olarak Türkçe öğretiminde beş temel beceriye yönelik yeterlik öz değerlendirmesi (ABD'deki devlet üniversiteleri ve özel üniversiteler örneği). [Yayımlanmamış Yüksek Lisans Tezi]. Sakarya Üniversitesi.

Kurt, E. (2019). Çocuklara yabancı dil olarak Türkçe öğretimi. [Yayımlanmamış Doktora Tezi]. Hacettepe Üniversitesi.

Kutlu, A. (2015). Yabancılara Türkçe ögretiminde Ömer Seyfettin'in Kaşağı ve Perili Köşk adlı hikâyelerinin A1-A2 sevyesine uyarlanması. [Yayımlanmamış Yüksek Lisans Tezi]. Gazi Üniversitesi.

Küçük, M. (2019). Yabancı dil olarak Türkçe öğretiminde b1 seviyesi için materyal olarak sözlük gelişstirme. [Yayımlanmamış Yüksek Lisans Tezi]. Hacettepe Üniversitesi.

Mattıuss1, R.G. Yabancllara Türkçe öğretiminde dinleme becerisinin geliştirilmesine yönelik görsel-işitsel materyal kullanımı üzerine bir araștırma. [Yayımlanmamış Yüksek Lisans Tezi]. Yıldız Teknik Üniversitesi.

Memiş, T.K. (2019). Yabancı dil olarak Türkçe ögretiminde B1 düzeyinde okuma sınavi geliştirme. [Yayımlanmamış Yüksek Lisans Tezi]. İstanbul Üniversitesi.

Mercan, E. (2018). Muzaffer İzgü öykülerindeki söylem biçeminin yabancı dil olarak Türkçe ögretimine uygunluğu. [Yayımlanmamış Yüksek Lisans Tezi]. Hacettepe Üniversitesi.

Metin, E. (2020). Yabancı dil olarak Türkçe öğretiminde eleştirel düşünme ve kültürlerarası yetkinliği gelişstirmeye yönelik stratejiler. [Yayımlanmamış Doktora Tezi]. Hacettepe Üniversitesi.

Minhaj, M. (2016). Yabancı dil olarak Türkçe öğretiminde Hindistanlı ögrrencilerin yazma becerisinde karışlaştıkları sorunlar. [Yayımlanmamış Yüksek Lisans Tezi]. Çanakkale Onsekiz Mart Üniversitesi.

Mutlu, T.Y. (2019). Türkçenin yabancı dil olarak ögretiminde Türk edebiyatı hikâyelerinin kullanıldığ y yaratıcı yazma çalışmalarının öğrenci öz yeterlilik ve yazma başarısı üzerindeki etkisi. [Yayımlanmamış Yüksek Lisans Tezi]. Marmara Üniversitesi.

Nalbant, S. (2019). Türkçenin yabancı dil olarak ögretiminde otantik öğrenmenin dinleme becerisine etkisi. [Yayımlanmamış Yüksek Lisans Tezi]. Dumlupınar Üniversitesi.

Nasuh, Y. (2019). Yabancılara Türkçe ögretimi kitaplarında dil düzeylerinegöre deyim ve kalıp söz kullanımı. [Yayımlanmamış Yüksek Lisans Tezi]. Çanakkale Onsekiz Mart Üniversitesi.

Ocak, B. (2019). Yabancı dil olarak Türkçe öğretiminde A2 düzeyinde konuşma sınavı geliştirme. [Yayımlanmamış Yüksek Lisans Tezi]. İstanbul Üniversitesi.

Oktay, M.R. (2015). Yabancılara Türkçe öğretimi ders kitaplarındaki metin altı sorularının Bloom Taksonomisi'ndeki bilişsel düzeyler açısından incelenmesi. [Yayımlanmamış Yüksek Lisans Tezi]. Başkent Üniversitesi.

Ormanşahin, A. (2018). Yabancı dil olarak Türkçe ögretiminde karşılaşılan sorunlar (Üsküp örneği). [Yayımlanmamış Yüksek Lisans Tezi]. Uşak Üniversitesi. 
Ömeroğlu, E. (2016). Yabancılara Türkçe öğretimi için hazırlanmış ders kitaplarının incelenmesi. [Yayımlanmamış Doktora Tezi]. Sakarya Üniversitesi.

Öncül, E. (2020). Yabancılara Türkçe öğretiminde kullanılan ders kitaplarında yer alan yazma etkinliklerinin diller için Avrupa ortak başvuru metni kapsamında değerlendirilmesi. [Yayımlanmamış Yüksek Lisans Tezi]. Nevşehir Hacı Bektaş Veli Üniversitesi.

Özaltun, H. (2018). Yabancllara Türkçe ögretiminde sesli metinlerin dinlenebilirlik açısından tanımlanmasl ve sinıflandırılması. [Yayımlanmamış Doktora Tezi]. İnönü Üniversitesi.

Özaydın, Ş. (2019). Yabancı dil olarak Türkçe ögretiminde edeb̂̂ metinlerin kullanımına ilişsin ögretici görüşlerinin incelenmesi. [Yayımlanmamış Yüksek Lisans Tezi]. Adıyaman Üniversitesi.

Özcan, E. (2019). Yabancı dil olarak Türkçe öğretiminde metin seçimi: Yeni Hitit B1 düzeyi. [Yayımlanmamış Yüksek Lisans Tezi]. Hacettepe Üniversitesi.

Özcan, H.Z. (2018). Türkçe'nin yabancı dil olarak öğretiminde temel seviye için kelime belirleme çalışması: Uşak Üniversitesi örneği. [Yayımlanmamış Yüksek Lisans Tezi]. Uşak Üniversitesi.

Özçelik, M. (2019). Türkçenin yabancı dil olarak öğretiminde aktif kelime hazinesinin geliştirilmesi. [Yayımlanmamış Yüksek Lisans Tezi]. Uşak Üniversitesi.

Özdemir, M. (2019). Yabancllara Türkçe ögrretiminde eylemsilerin biçim-anlam ve kullanım açısından değerlendirilmesi. [Yayımlanmamış Yüksek Lisans Tezi]. Çanakkale Onsekiz Mart Üniversitesi.

Özdeniz, S. (2019). Yabancı dil olarak türkçe ögretiminde dil bilgisini destekleyici metin odaklı malzeme geliştirme (A1 düzeyi): Okuma beceresi örneği. [Yayımlanmamış Yüksek Lisans Tezi]. Hacettepe Üniversitesi.

Özdeş, M. (2019). Yabancılara Türkçe öğretiminde yazılı akran ve ögrretmen geribildirimleri üzerine karşılaştırmalı bir inceleme. [Yayımlanmamış Yüksek Lisans Tezi]. Mersin Üniversitesi.

Özdin, A. (2020). Türk masallarının yabancılara Türkçe ögretiminde okuma metni olarak uyarlanması. [Yayımlanmamış Yüksek Lisans Tezi]. Necmettin Erbakan Üniversitesi.

Özer, H. (2019). Yabancılara Türkçe öğretimi konusunda Türkçe yayımlanmış bilimsel çalışmaların bibliyografyası ve doktora tezlerinin diller için Avrupa ortak başvuru metni bağlamında analizi. [Yayımlanmamış Yüksek Lisans Tezi]. Muğla Sitkı Koçman Üniversitesi.

Özet, A.T. (2019). Nasreddin Hoca fikralarının yabancılara Türkçe ögretiminde okuma metni olarak düzenlenmesi. [Yayımlanmamış Yüksek Lisans Tezi]. Necmettin Erbakan Üniversitesi.

Özmen, C. (2019). Yabancı dil olarak Türkçe ögretiminde metin değistirim teknikleriyle öykülerin yeniden oluşturulması. [Yayımlanmamış Doktora Tezi]. Hacettepe Üniversitesi.

Öztürk, A.G. (2015). Dîvânu Lugâti't-Türk'te yer alan atasözlerinin yabancllara Türkçe ögretiminde kültür aktarımına katkısı üzerine bir değerlendirme. [Yayımlanmamış Yüksek Lisans Tezi]. Başkent Üniversitesi.

Pali, O. (2016). Yabancı dil olarak Türkçe ögretimi açısından Türkçe ve Ukraynaca dil yapılarının karşılaştırılması. [Yayımlanmamış Yüksek Lisans Tezi]. İstanbul Üniversitesi. 
Pourıssa, D. (2018). Türkçenin yabancı dil olarak öğretiminde insan organlarını konu alan Türkçe ve Farsça deyimlerin karşılaştırılması. [Yayımlanmamış Yüksek Lisans Tezi]. Marmara Üniversitesi.

Ramanenkava, A. (2020). Yabancı dil olarak Türkçe öğretiminde dil ihtiyaçlarının belirlenmesi: Belarus örneği. [Yayımlanmamış Yüksek Lisans Tezi]. Dokuz Eylül Üniversitesi.

Rebahan, Z. (2019). Yabancı dil olarak Türkçe öğretiminde kullanılan ders kitaplarındaki konuşma etkinliklerinin göreve dayalı dil ögretimine göre incelenmesi. [Yayımlanmamış Yüksek Lisans Tezi]. Muğla Sitkı Koçman Üniversitesi.

Sağlık, H. (2018). Türkçenin yabancı dil olarak öğretiminde kullanılan ders kitaplarında yer alan konuşma becerisi etkinliklerinin Avrupa Dil Gelişim Dosyası doğrultusunda değerlendirilmesi. [Yayımlanmamış Yüksek Lisans Tezi]. Yıldız Teknik Üniversitesi.

Saraç, Ş. (2018). Türkçenin yabancı dil olarak ögretimine İngiliz katkısı. [Yayımlanmamış Doktora Tezi]. Hacettepe Üniversitesi.

Sarıbaş, M. (2014). Avrupa dilleri öğretimi ortak çerçeve metnine göre yabancılara Türkçe ögretiminde A1-A2-B1-B2 seviyesinde okuma etkinlikleri ve örnekleri. [Yayımlanmamış Yüksek Lisans Tezi]. Gazi Üniversitesi.

Sarıdede, B. (2020). Yabancı dil olarak Türkçe öğretiminde yabancıların eşdizimsel örüntüleri algılamaları. [Yayımlanmamış Yüksek Lisans Tezi]. İstanbul Üniversitesi, İstanbul.

Sarıman, G. (2016). Yabancı dil olarak Türkçe ögretiminde bilgisayar destekli eğitimin kelime vurgulama becerisine etkisi. [Yayımlanmamış Yüksek Lisans Tezi]. Muğla Sitkı Koçman Üniversitesi.

Sarıtaş, H. (2014). Kültürel yaklaşımın Türkçenin yabancı dil olarak öğretiminde uygulanması ve ögrenci görüşleri. [Yayımlanmamış Yüksek Lisans Tezi]. Dokuz Eylül Üniversitesi.

Savuran, Y. (2020). Türkçenin yabancı dil olarak ögretiminde temel ve ara düzey betimleyicilerin geliştirilmesi. [Yayımlanmamış Doktora Tezi]. Eskişehir Osmangazi Üniversitesi.

Saydam, M. (2018). Kelime öğretimi stratejileri açısından yabancı dil olarak Türkçe öğretimi kitapları üzerine bir araştırma. [Yayımlanmamış Yüksek Lisans Tezi]. Yıldız Teknik Üniversitesi.

Sayır, M.F. (2020). Yabancılara Türkçe ögretiminde çoklu ortam dipnotlarılla kelime ögretimi sürecinin etkinlik kuramı çerçevesinde değerlendirilmesi. [Yayımlanmamış Doktora Tezi]. Atatürk Üniversitesi.

Serin, N. (2017). Yabancı dil olarak Türkçe öğretimi için hazırlanmış ders kitapları ile bu kitapları kullanan öğrencilerin söz varlığının karşılaştırılması. [Yayımlanmamış Doktora Tezi]. Atatürk Üniversitesi.

Sertoğlu, S.T. (2019). Yabancı dil olarak Türkçe öğretimi kapsamında 'İstanbul yabancılar için Türkçe' setinin görsel düzen açısından incelenmesi. [Yayımlanmamış Yüksek Lisans Tezi]. İstanbul Üniversitesi.

Sever, P. (2019). Yeni Hitit dil ögretim seti ile yedi iklim dil ögretim setinin Türkçenin yabancı dil olarak ögretiminde kültür aktarımı açısından karşılaştırılması. [Yayımlanmamış Yüksek Lisans Tezi]. Nevşehir Hacı Bektaş Veli Üniversitesi.

Seyedi, G. (2019). Yabancı dil olarak Türkçe ögretiminde akademik yazma öğretimi. [Yayımlanmamış Doktora Tezi]. Hacettepe Üniversitesi. 
Sezen, Y. (2020). Yabancılara Türkçe ögretiminde tv dizisi kullanmanın atasözü ve deyim ögretmedeki etkisi (Aslan ailem tv dizisi örneği). [Yayımlanmamış Yüksek Lisans Tezi]. Uşak Üniversitesi.

Shırazı, F. (2018). Ana dili Farsça olanlara yabancı dil olarak Türkçe öğretiminde ortak dil unsurlarından yararlanma: Atasözleri, deyimler ve kalıp sözler. [Yayımlanmamış Yüksek Lisans Tezi]. Gazi Üniversitesi.

Sivrioğlu, S. (2014). Yabancı dil olarak Türkçe ögretiminde yaratıcı dramanın konuşma becerisine etkisi. [Yayımlanmamış Yüksek Lisans Tezi]. Ankara Üniversitesi.

Sönmez, E. (2019). Türkçenin yabancı dil olarak öğretiminde kullanılan ders kitaplarının Avrupa Dilleri Öğretimi Ortak Çerçevesi açısından incelenmesi [Yayımlanmamış Yüksek Lisans Tezi]. Pamukkale Üniversitesi.

Sumruk. H. (2019). Yabancı dil olarak Türkçe öğretiminde etkileşim ve konuşma çözümlemesi yöntemiyle kelime öğretimi: A2 düzeyi. [Yayımlanmamış Yüksek Lisans Tezi]. Hacettepe Üniversitesi.

Süner, R. (2018). Yabancı dil olarak Türkçe öğretiminde yazınsal metinlerin B1 düzeyine uyarlanmast: Eskici örneği. [Yayımlanmamış Yüksek Lisans Tezi]. Hacettepe Üniversitesi.

Şen, E. (2015). Iktisadi ve idari bilimler Türkçesinin incelenmesi ve yabancı dil olarak Türkçe ögretiminde kullanımı. [Yayımlanmamış Yüksek Lisans Tezi]. Dokuz Eylül Üniversitesi.

Şen, E. (2018). Türkçenin yabancı dil olarak öğretiminde aktif öğrenmenin üretici becerilerin geliştirilmesine etkisi (Gem örneği). [Yayımlanmamış Yüksek Lisans Tezi]., Nevşehir Hacı Bektaş Veli Üniversitesi.

Şenden, Y.E. (2017). Türkçenin yabancı dil olarak öğretiminde kalıp sözlerin kullanımına yönelik etkinlik örneklerinin başarı üzerindeki etkileri. [Yayımlanmamış Yüksek Lisans Tezi]. Gaziosmanpaşa Üniversitesi.

Şengül, K. (2016). Yabancı dil olarak Türkçe öğretiminde dil öğrenme stratejilerine dayalı etkinliklerin anlama becerileri ile dil bilgisine yönelik başarıya, kalıcılığa ve Türkçeye yönelik tutuma etkisi. [Yayımlanmamış Doktora Tezi]. Atatürk Üniversitesi.

Şenyiğit, Y. (2020). Yabancılara Türkçe öğretiminde sözlü dilin kelime slkllğl ve A1-A2 seviye sözlüğ̈̈. [Yayımlanmamış Doktora Tezi]. Sakarya Üniversitesi.

Şimşek, E. (2019). Yabancılara Türkçe öğretiminde kullanılan ders kitaplarındaki metinlerin okunabilirlik düzeyleri açısından incelenmesi. [Yayımlanmamış Yüksek Lisans Tezi]. Gaziantep Üniversitesi.

Şimşek, P. (2017). Türkçenin yabancı dil olarak ögretiminde, ögrencilerin ana dilleri ve mensup oldukları dil ailelerinin Türkçe yazma becerisine etkisi. [Yayımlanmamış Doktora Tezi]. Ankara Üniversitesi.

Şimşek, R. (2016). Yabancılara Türkçe öğretiminde kullanılan ders kitaplarının temel dil becerileri bağlamında karşılaş̧tırmalı olarak incelenmesi. [Yayımlanmamış Yüksek Lisans Tezi]. Nevşehir Hacı Bektaş Veli Üniversitesi.

Şimşek, R. (2019). Subliminal bir güç göstergesi: yabancı dil olarak Türkçe ögrretiminde ders kitapları. [Yayımlanmamış Doktora Tezi]. İnönü Üniversitesi.

Tabak, G. (2017). Türkçenin yabancı dil olarak öğretiminde dijital öykü kullanımı. [Yayımlanmamış Doktora Tezi]. Erciyes Üniversitesi. 
Takıl, N.B. (2014). Türkçenin yabancı dil olarak öğretiminde iletişimsel yaklaşımın yazma becerisine etkisi. [Yayımlanmamış Doktora Tezi]. Gazi Üniversitesi.

Tanju, B. (2019). Yabancı dil olarak Türkçe ögretiminde A1 ve A2 düzeyleri için önerilen iletişimsel konuşma etkinlikleri. [Yayımlanmamış Yüksek Lisans Tezi]. İstanbul Üniversitesi.

Tarhan, Z. (2020). Sanal gerçeklik araçlarının yabancı dil olarak Türkçe ögretiminde sözcük ögrenimine etkisi ve akılda tutmadaki verimliliği. [Yayımlanmamış Yüksek Lisans Tezi]. İstanbul Üniversitesi.

Taşdemir, O. (2017). Yabancllara Türkçe ögrretiminde özel yazmanın yazma kaygısına ve yazma eğilimine etkisinin incelenmesi. [Yayımlanmamış Yüksek Lisans Tezi]. Dokuz Eylül Üniversitesi.

Tatan, O.Ö. (2018). Yabancı dil olarak Türkçe ögretimi ders kitaplarında kültür aktarımı: Yedi İklim Türkçe Öğretim Seti örneği (A1-A2 düzeyi). [Yayımlanmamış Yüksek Lisans Tezi]. Gaziosmanpaşa Üniversitesi.

Tataroğlu, S. (2019). Yabancı dil olarak Türkçe öğretiminde yaratıcı drama uygulamalarının konuşma becerisine etkisi. [Yayımlanmamış Yüksek Lisans Tezi]. İstanbul Üniversitesi.

Tekin, E. (2019). Yabancı dil olarak Türkçe öğretimi kitaplarında atasözü ve deyimlerin öğretim stratejileri üzerine bir durum tespiti. [Yayımlanmamış Yüksek Lisans Tezi]. Yıldız Teknik Üniversitesi.

Tekin, G. (2020). Türkçenin yabancı dil olarak ögretiminde sesletim eğitimi. [Yayımlanmamış Doktora Tezi]. Bolu Abant İzzet Baysal Üniversitesi.

Tiraşoğlu, C. (2019). Yabancllara Türkçe öğretiminde söz varlığını gelişstirmeye yönelik web 2.0 araçları: Kahoot! Örneği. [Yayımlanmamış Yüksek Lisans Tezi]. Akdeniz Üniversitesi.

Tok, A. (2015). Dîvânu Lugâti't-Türk'te yer alan yabancılara Türkçe öğretimi unsurları. [Yayımlanmamış Yüksek Lisans Tezi]. Başkent Üniversitesi.

Turan, F.S. (2014). Türkçenin yabancı dil olarak öğretimi tarihinde Arthur Lumley Davids'in "A Grammar of the Turkish Language" adl eseri üzerine bir inceleme. [Yayımlanmamış Yüksek Lisans Tezi]. Firat Üniversitesi.

Tursum, L. (2019). Boşnakçada yaşamaya devam eden Türkizmler'in Bosna Hersek'te yabancı dil olarak Türkçe ögretiminde kullanımı: Al düzeyi. [Yayımlanmamış Yüksek Lisans Tezi]. Hacettepe Üniversitesi.

Tülü, T. (2014). Yabancı dil olarak Türkçe öğretimi sinıflarında sözcük öğretiminde tanım türlerinden yararlanma. [Yayımlanmamış Yüksek Lisans Tezi]. Dokuz Eylül Üniversitesi.

Türk, H. (2018). Yabancılara Türkçe ögretiminde bir izlence tasarımı ve kültürel ögelerin hikâye kitapları aracılığıyla aktarımı. [Yayımlanmamış Yüksek Lisans Tezi]. İhsan Doğramacı Bilkent Üniversitesi.

Türker, M.S. (2018). Yabancı dil olarak Türkçe öğretiminde blog kullanımının okuma becerisine etkisi. [Yayımlanmamış Doktora Tezi]. Hacettepe Üniversitesi.

Ummak, H. (2018). Yabancı dil olarak Türkçe ögrretiminde kullanılan 'Kolay gelsin' ve 'Ístanbul' ders kitaplarında kültürlerarası ögrrenme. [Yayımlanmamış Yüksek Lisans Tezi]. İstanbul Üniversitesi.

Ural, O.K. (2016). Yabancı dil olarak Türkçe ögrretiminde araç gereç ve teknoloji kullanım yeterlilikleri. [Yayımlanmamış Yüksek Lisans Tezi]. İstanbul Üniversitesi. 
Ünal, E.T. (2020). Türkçenin Yabancı Dil Olarak Öğretiminde Ders Kitaplarında Kullanılan Sesletim Yöntem ve Uygulamaları. [Yayımlanmamış Yüksek Lisans Tezi]. Nevşehir Hacı Bektaş Veli Üniversitesi.

Ünal, İ. (2019). Türkçenin yabancı dil olarak öğretiminde temel seviye (A1-A2 düzeyi) hedef sözcük belirleme çalışması. [Yayımlanmamış Yüksek Lisans Tezi]. Marmara Üniversitesi.

Ünay, M. (2020). Yabancı dil olarak Türkçe öğretimi kitapları okuma metinlerinde bağlam temelli sözcük öğretim yöntemi kullanımı. [Yayımlanmamış Yüksek Lisans Tezi]. İstanbul Üniversitesi.

Ünsal, B.S. (2020). Yabancı dil olarak Türkçe ögretiminde "Keloğlan" çizgi filminin kültürel etkileşim ögesi olarak incelenmesi. [Yayımlanmamış Yüksek Lisans Tezi]. Nevşehir Hacı Bektaş Veli Üniversitesi.

Ünver, B. (2019). Türkçenin yabancı dil olarak öğretiminde sınıf içi ölçme değerlendirme uygulamaları. [Yayımlanmamış Yüksek Lisans Tezi]. Bolu Abant İzzet Baysal Üniversitesi.

Yabacı, L.N. (2020). Yabancı dil olarak Türkçe ögretimi kitaplarında ikilemelerin yapı, işlev ve anlam açısından değerlendirilmesi. [Yayımlanmamış Yüksek Lisans Tezi]. Hacettepe Üniversitesi.

Yalçın, Ç. (2018). Yabancı dil olarak Türkçe öğretimi ders kitaplarında yer alan dinleme etkinliklerinin dil öğrenme stratejileri açısından incelenmesi. [Yayımlanmamış Yüksek Lisans Tezi]. Nevşehir Hacı Bektaş Veli Üniversitesi.

Yaşar, S.A. (2019). Yabancılara Türkçe öğretiminde metin uyarlama ve Memduh Şevket Esendal'ın "Pazarlı" hikâyesinin A2 seviyesine göre uyarlanmast. [Yayımlanmamış Yüksek Lisans Tezi]. Dumlupınar Üniversitesi.

Yavuzel, S.T. (2020). Türkçenin yabancı dil olarak ögretiminde kültürel aktarım açısından türkülerin önemi. [Yayımlanmamış Yüksek Lisans Tezi]. Bursa Uludağ Üniversitesi.

Yayan, H. (2019). Yabancılara Türkçe ögretiminde Refik Halit Karay'ın eskici ve testi adlı hikâyelerinin A2 seviyesine uyarlanması. [Yayımlanmamış Yüksek Lisans Tezi]. Nevşehir Hacı Bektaş Veli Üniversitesi.

Yazok, Z. (2020). Yabancılara Türkçe ögrretimi kapsamında Kemalettin Çalık'ın Piri Reis adlı eserinin B1 seviyesinde sadeleştirilmesi. [Yayımlanmamış Yüksek Lisans Tezi]. Dicle Üniversitesi.

Yeşilyurt, E.T. (2019). Yabancılara Türkçe öğretiminde kültür aktarımında Nasreddin Hoca fikralarının b2 seviyesinde değerlendirilmesi. [Yayımlanmamış Yüksek Lisans Tezi]. Y1ldız Teknik Üniversitesi.

Yeşilyurt, Ş. (2016). Türkçenin yabancı dil olarak ögrretiminde duygu durumlarını yansıtan kısa filmlerin oluşturulması ve ögrenci başarısına etkisi. [Yayımlanmamış Doktora Tezi]. Gazi Üniversitesi.

Yıldırım, M. (2018). Yabancılara Türkçe öğretiminde yazma gelişim dosyası uygulaması. Yayımlanmamış Doktora Tezi, Gazi Üniversitesi.

Yıldız, E. (2018). Yabancılara Türkçe öğretimi dersinin Türkçe öğretmen adaylarının görüşleri bağlamında değerlendirilmesi. [Yayımlanmamış Yüksek Lisans Tezi]. Gaziosmanpaşa Üniversitesi. 
Yıldız, G.T. (2019). Kaynak eserlerin Türkçenin yabancı dil olarak öğretiminde kullanılması: Evliya Çelebi'nin Seyahatname'si. [Yayımlanmamış Yüksek Lisans Tezi]. Marmara Üniversitesi.

Yılmaz, E. (2019). Diller İçin Avrupa Ortak Başvuru Metni çerçevesinde yabancı dil olarak Türkçe ögretimi programı önerisi: A1-A2. [Yayımlanmamış Yüksek Lisans Tezi]. Hacettepe Üniversitesi.

Yılmaz, İ. (2014). Yabancı dil olarak Türkçe ögrretiminde tamamlayıcı ölçme ve değerlendirme yöntemlerinin deyim ögretiminde kullanılmasına yönelik bir inceleme. [Yayımlanmamış Doktora Tezi]. Atatürk Üniversitesi.

Yılmaz, Ö. (2018). Yabancı dil olarak Türkçe öğretiminde metin odakl dilbilgisi öğretimi. [Yayımlanmamış Yüksek Lisans Tezi]. İstanbul Üniversitesi.

Yücel, H. (2019). Türkçenin yabancı dil olarak ögretiminde güdüleme stratejilerine yönelik önem algıları ölçeğinin geliştirilmesi. [Yayımlanmamış Doktora Tezi]. Hacettepe Üniversitesi. Zengin, Z.Ş. (2019). Türkçenin yabancı dil olarak ögretimine yönelik hazırlanan ders materyallerinde uygulamal halk bilimi alanındaki konulara ait tema ve söz varlı̆̆ının kullanımı. [Yayımlanmamış Yüksek Lisans Tezi]. Ankara Hacı Bayram Veli Üniversitesi.

Zorpuzan, R. (2019). Türkçenin yabancı dil olarak ögretiminde kavram haritalarının kelime ögretimi üzerine etkisi. [Yayımlanmamış Yüksek Lisans Tezi]. Bolu Abant İzzet Baysal Üniversitesi.

Zorpuzan, S. (2018). Türkçenin yabancı dil olarak öğretiminde kullanılan kitaplardaki kalıp söz ve deyim varlı̆̆ı. [Yayımlanmamış Yüksek Lisans Tezi]. Bolu Abant İzzet Baysal Üniversitesi.

\section{Beyan ve Açıklamalar (Disclosure Statements)}

1. Araştırmacıların katkı oranı beyanı / Contribution rate statement of researchers:

Birinci Yazar/First author \%50 İkinci Yazar/Second author \%50

2. Yazarlar tarafından herhangi bir çıkar çatışması beyan edilmemiştir (No potential conflict of interest was reported by the authors). 